\title{
Bathymetric Survey of the St. Anthony Channel (Croatia) Using Multibeam Echosounders (MBES) - A New Methodological Semi-Automatic Approach of Point Cloud Post-Processing
}

\author{
Ante Šiljeg ${ }^{1} \mathbb{D}$, Ivan Marić ${ }^{1, *(\mathbb{D})}$, Fran Domazetović ${ }^{1}\left(\mathbb{D}\right.$, Neven Cukrov $^{2} \mathbb{D}$, Marin Lovrić $^{2}$ and Lovre Panđa $^{1}$ \\ 1 Department of Geography, University of Zadar, 23000 Zadar, Croatia; asiljeg@unizd.hr (A.̌̌.); \\ fdomazeto@unizd.hr (F.D.); lpanda@unizd.hr (L.P.) \\ 2 Department for Marine and Environmental Research, Ruđer Bošković Institute, 10000 Zagreb, Croatia; \\ ncukrov@irb.hr (N.C.); marinl@irb.hr (M.L.) \\ * Correspondence: imaric1@unizd.hr; Tel.: +385-958219909
}

Citation: Šiljeg, A.; Marić, I.; Domazetović, F.; Cukrov, N.; Lovrić, M.; Panđa, L. Bathymetric Survey of the St. Anthony Channel (Croatia) Using Multibeam Echosounders (MBES)—A New Methodological Semi-Automatic Approach of Point Cloud Post-Processing. J. Mar. Sci. Eng. 2022, 10, 101. https://doi.org/ 10.3390/jmse10010101

Academic Editor: Anders Jensen Knudby

Received: 9 December 2021

Accepted: 11 January 2022

Published: 13 January 2022

Publisher's Note: MDPI stays neutral with regard to jurisdictional claims in published maps and institutional affiliations.

Copyright: (C) 2022 by the authors. Licensee MDPI, Basel, Switzerland. This article is an open access article distributed under the terms and conditions of the Creative Commons Attribution (CC BY) license (https:// creativecommons.org/licenses/by/ $4.0 /)$.

\begin{abstract}
Multibeam echosounders (MBES) have become a valuable tool for underwater floor mapping. However, MBES data are often loaded with different measurement errors. This study presents a new user-friendly and methodological semi-automatic approach of point cloud post-processing error removal. The St. Anthony Channel (Croatia) was selected as the research area because it is regarded as one of the most demanding sea or river passages in the world and it is protected as a significant landscape by the Šibenik-Knin County. The two main objectives of this study, conducted within the Interreg Italy-Croatia PEPSEA project, were to: (a) propose a methodological framework that would enable the easier and user-friendly identification and removal of the errors in MBES data; (b) create a high-resolution integral model (MBES and UAV data) of the St. Anthony Channel for maritime safety and tourism promotion purposes. A hydrographic survey of the channel was carried out using WASSP S3 MBES while UAV photogrammetry was performed using Matrice 210 RTK V2. The proposed semi-automatic post-processing of the MBES acquired point cloud was completed in the Open Source CloudCompare software following five steps in which various point filtering methods were used. The reduction percentage in points after the denoising process was $14.11 \%$. Our results provided: (a) a new user-friendly methodological framework for MBES point filtering; (b) a detailed bathymetric map of the St. Anthony Channel with a spatial resolution of $50 \mathrm{~cm}$; and (c) the first integral (MBES and UAV) high-resolution model of the St. Anthony Channel. The generated models can primarily be used for maritime safety and tourism promotion purposes. In future research, ground-truthing methods (e.g., ROVs) will be used to validate the generated models.
\end{abstract}

Keywords: multibeam echosounders (MBES); St. Anthony Channel; CloudCompare; integral model

\section{Introduction and Background}

Multibeam echosounders (MBES) are recognized as one of the most powerful and popular mapping technologies available for modern underwater (e.g., sea, river, lake) exploration [1-5]. MBES have been publicly available since the 1970s [6-8]. MBES are now advanced to a level where the ultra-high-resolution $(\mathrm{cm})$ of underwater floor mapping [9] is performed at a similar spatial resolution as the remote sensing of the terrestrial environment [10]. MBES systems can typically collect high-resolution bathymetry (the travel time of the sound), water column [11], and backscatter (the intensity of the returned signal) data simultaneously [1,12-14]. Therefore, the MBES systems have a wide range of applications, which include: the acquisition of bathymetric data [15-17]; hydrographic charting [4,7,18]; habitat mapping $[4,9,12,18-20]$; the analysis of the benthic fauna [21]; the production of thematic maps [22]; tidal channels modeling [23]; geomorphometric analysis [2,24-26]; seafloor facies classification $[4,27,28]$; habitat suitability modeling $[29,30]$; the mapping of underwater archaeological sites [31-36]; morphological and sedimentological evolution [7,37]; the 
mapping of seafloor substrates [38]; geohazard assessments [39]; analyzing the challenges associated with climate change [40]; modeling the ocean circulation [41]; monitoring marine infrastructure development [42]; fisheries assessments [43]; the detection of areas suitable for seafloor mining [44]; marine conservation [45]; marine protected area planning [46]; and the mapping of submerged landscapes [47]. Lecours et al. [2] provided a detailed overview of the possible applications of multibeam data. However, despite MBES systems being state-of-the-art and even with careful and diligent data acquisition that follows all rules and recommended guidelines, the collected point clouds may contain undesired errors due to various external factors. The transformation of point cloud data into more complex accurate models is only possible if the data are processed in an appropriate manner, respective to the quality level of input data provided [48]. The rapidly evolving MBES underwater mapping technology generates large amounts of data [14,49-52]. Some less efficient MBES can collect around 30 million points per hour in shallow water [51]. MBES systems, in most cases, deliver data in the form of a georeferenced file consisting of a point (xyz) cloud with billions of individual points [8], 48, pp. 187, [53]. In most cases, the acquired raw MBES data are processed in gridded DTM at the best possible resolution [7]. These raw 3D point clouds are often contaminated with noise and outliers [54-56]. The outliers can be defined as inaccurate data (unordinary value) collected during an MBES survey $[8,57]$ that statistically deviate from the other elements of the sample [50], meaning that they are inconsistent or atypical values [58]. The outlier rate is much higher in a MBES system than in a terrestrial survey due to the complexity of the data acquisition process. It can affect up to $25 \%$ of the data, depending on the sensor characteristics and environmental conditions [8]. This type of error can be the result of user errors at the time of acquisition (gross error) [58], acoustic contrast linked to the presence of hydrothermal vent or fish [54], the malfunction of the MBES [59], the poor performance of the algorithms, bad weather conditions, the presence of air bubbles in the face of the transducers, etc. $[8,51,54]$. Therefore, the postprocessing of stored MBES data is regarded as the most important step in hydroacoustic measurements ([52], p. 259). Although commercial robust automatic cleaning algorithms exist [53,54] and some authors (such as [1], p. 3) state that "processing MBES bathymetry data is well-established and implemented in the software provided by the sonar manufacturers", it is widely recognized that the post-processing of MBES data is a challenging task $[7,50,51,53,54,60]$ from both hydrographic and technological perspectives [48,61].

Therefore, the automatic cleaning of MBES data is recognized as a critical issue in data processing [8]. Most of the commercially available automatic cleaning methods rely on the CUBE (Combined Uncertainty and Bathymetry Estimator) algorithm [8,51,54]. CUBE estimates multiple depths for a single grid node, depending on the sounding data variation [23]. However, the careful examination of the MBES data by the user is considered necessary [7]. The application of these automatic processing methods is recommended by the International Hydrographic Organization (IHO) S-44 standard ([8], p. 254). The majority of algorithms for outlier detection are based on non-supervised methods where the dataoriented detection of outliers is performed by working directly on the data [8]. Data cleaning is often performed manually [54] and it is a time-consuming process that can take several times longer than a multibeam survey $[8,51,53,54]$. Data point clouds acquired with MBES systems often contain irregularities, which can include: strong variability in point density; missing data (holes) [56]; overlapping points; and errors (systematic errors, abnormal sounding/outliers, and noise/random errors) $[8,50,54,56]$ caused by the scattering characteristics of the environment $[48,62]$. These automatic cleaning algorithms are also not always perfect, and they can result in the propagation of errors and the loss of information [7]; therefore, the inspection and data point cleaning must be finalized manually by the user [50,53]. For these reasons, the processing of the MBES points clouds can be challenging and time-consuming, especially in the context of generating 3D models [48].

Le Deunf et al. [8], Ferreira et al. [51], Makar et al. [52], and Calder et al. [60] provide excellent overviews of the methods used in filtering collected MBES data. However, these techniques can be difficult to use and mostly, they are implemented in commercial packages, 
require high user expertise, and are often semi-automated [51]. Therefore, the two main objectives of this study were to:

(1) propose a new user-friendly methodological framework that would enable the easier identification and removal of the different errors [51] in MBES data, which would achieve a balance between the denoising and preservation of underwater features;

(2) create a high-resolution 3D model and detailed integral digital bathymetric models (DBM) model of the St. Anthony Channel seafloor, primarily for maritime safety and tourism promotion purposes.

The dataset presented in this paper contains high-resolution MBES data acquired within the INTERREG PEPSEA Italy-Croatia (Protecting the Enclosed Parts of the Adriatic Sea from Pollution) project for the wider area of the St. Anthony Channel (Croatia). The MBES data were acquired using the high-resolution, professional level WASSP (Wide Angle Sonar Seafloor Profiler) S3 (Survey3) multibeam sounder. This new methodological framework, based on open access CloudCompare 3D point cloud editing and processing software, can be extremely useful when a user does not have a hydrographic survey package for the processing of MBES data or has not achieved the high level of expertise needed to use more demanding algorithms.

Study Area

The St. Anthony Channel ( $\varphi=43^{\circ} 43^{\prime} 35.9^{\prime \prime} \mathrm{N}, \lambda=15^{\circ} 51^{\prime} 56.6^{\prime \prime}$ E) (World Geodetic System (WGS) 1984 Geographic Coordinate System) is part of the Krka River estuary and is located in the middle of the eastern coast of the Adriatic Sea in Šibenik-Knin County (Croatia), near the city of Šibenik. It is a strait that connects Šibenik Bay and the port of Šibenik to the Adriatic Sea (Figure 1).

The Krka River estuary is formally protected as a NATURA 2000 site ("Krka Mouth") and the St. Anthony Channel also became protected by the Šibenik-Knin County in 1974 as a "Significant Landscape". It is regarded as one of the 50 most demanding sea or river passages in the world (Belamarić et al., 2016, pp. 142). The number of vessels during the summer months exceeds 1500 per day [63].

The coastline of the channel is exceptionally steep and rocky and interspersed with shallows [64]. It is around $2.5 \mathrm{~km}$ long, $140 \mathrm{~m}$ wide at the narrowest part, and $220 \mathrm{~m}$ wide at the entrance. Lovrinčević [65] states that the channel is deeper than $40 \mathrm{~m}$, citing the Hydrographic Institute of the Republic of Croatia (Split). Belamarić et al. [64] state that the channel is $23-30 \mathrm{~m}$ deep, without a reference. The channel developed its final shape 10,000 years ago when the lower course of the river Krka was submerged. Therefore, the channel was once the canyon of the river Krka, and traces of this riverbed reach the Adriatic Sea. At the bottom of the channel, tufa barriers have been found which indicates that these were tufa waterfalls in the past. 

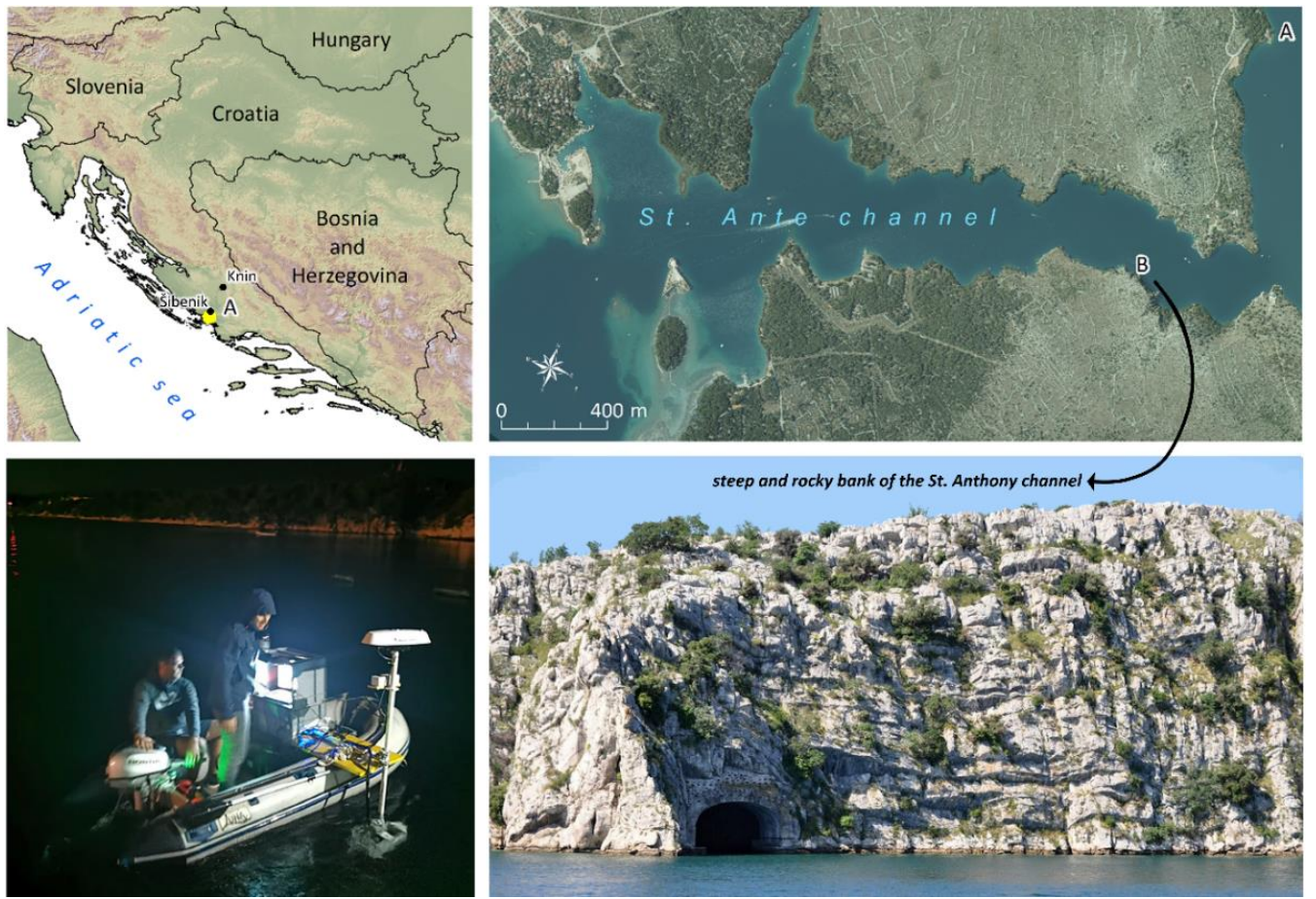

Figure 1. The geographic location of the St. Anthony Channel in Šibenik-Knin County (Croatia).

\section{Materials and Methods}

\subsection{Multibeam Echosounder (MBES) Survey}

A hydrographic survey of the St. Anthony Channel was carried out in October 2020. The MBES survey covered around a $1.2 \mathrm{~km}^{2}$ area. A small rubber boat Luna, about $3 \mathrm{~m}$ long, was used in the MBES survey (Figure 2). It was an optimal solution because the smaller dimensions and the draft made the installation of the MBES components easier. The MBES survey was performed by the members of Geospatial Analysis Laboratory (Geospatial Analysis Laboratory (http://gal.unizd.hr/, accessed at: 7 January 2022) (GAL)) and members of the Department for Marine and Environmental Research (Department for Marine and Environmental Research, Ruđer Bošković Institute (https: / /www.irb.hr/eng/ Divisions/Division-for-Marine-and-Environmental-Research, accessed at: 7 January 2022) (Ruđer Bošković Institute)).
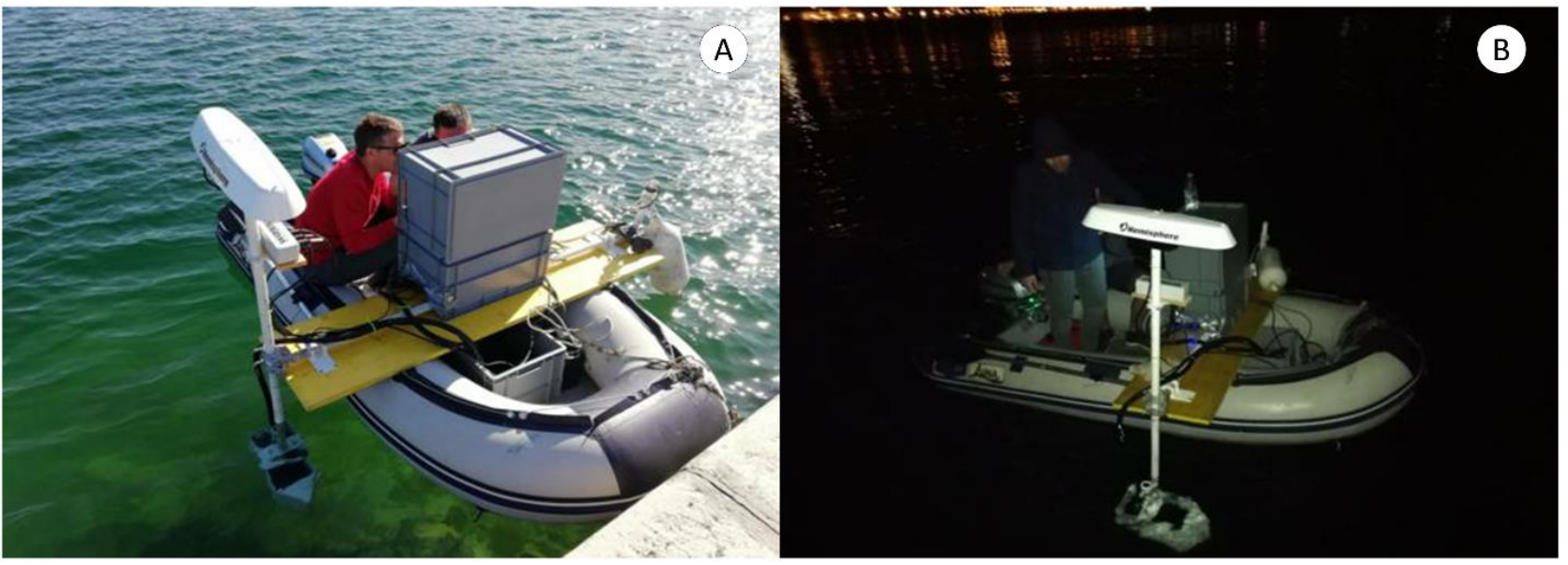

Figure 2. The small boat Luna at (A) the beginning and (B) the end of the MBES survey. 
The MBES survey included a wide range of activities based on the Manual of Hydrography [66]. Therefore, the MBES survey consisted of several phases.

Survey specifications: The requirements for the MBES survey were defined within the Interreg Italy-Croatia PEPSEA project. The decision-makers and product users wanted to obtain a high-resolution 3D model, detailed digital bathymetric model, and integrated model (spatial resolution around $1 \mathrm{~m}$ ) of the St. Anthony Channel. The project defined the minimum area to be recorded with the desired spatial resolution for the final DBM. The desired outputs were determined within the project due to the need to generate the accurate physical dimensions, characteristics, and shape [67] of the seafloor. Although the bathymetric database has grown substantially over the last decade, it is almost impossible to find such detailed datasets at the regional level and even the large areas remain sparsely mapped $[67,68]$.

Survey planning $($ : Detailed planning and organization and the exact area of the MBES survey was carried out.

Background spatial data: The background spatial data (e.g., electronic nautical charts, aerial photogrammetry) were identified and recognized for use. They included a combination of UAV photogrammetry data and the use of electronic nautical charts of the St. Anthony Channel. The UAV photogrammetry of the St. Anthony Channel was conducted a few days before the MBES survey. These data were used to create the integrated model of the St. Anthony Channel. The high-resolution digital orthophoto (DOP) and digital surface model (DSM) with a spatial resolution of $5 \mathrm{~cm}$ were generated from aerial imagery collected by the UAV Matrice 210 RTK V2 (Figure 3). A double grid mission with front and side overlaps of $80 \%$ was used. The missions were planned in ArcMap and the flight was performed in DJI GS Pro. The image workflow process was performed in Agisoft Metashape 1.5.1.

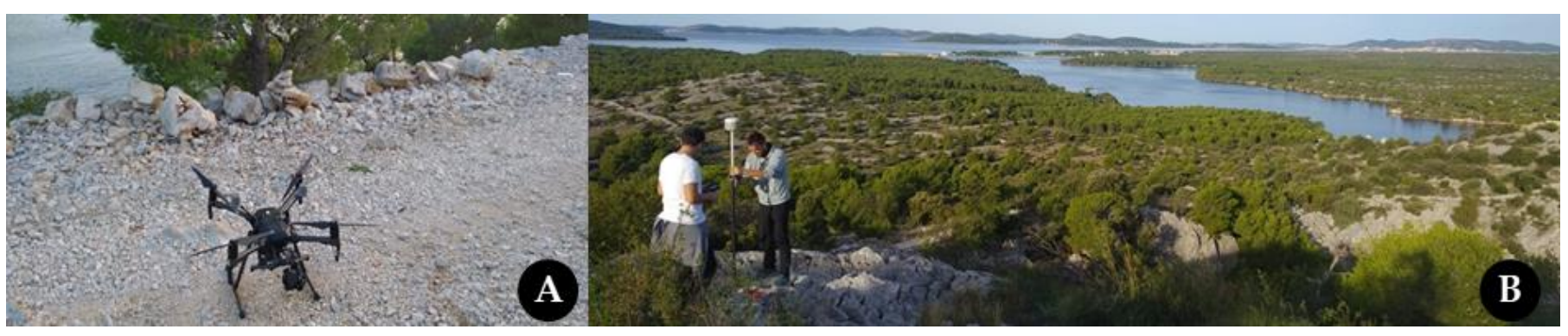

Figure 3. (A) The UAV Matrice 210 RTK V2; (B) the collecting ground control (GCP) and check point (CP).

Limiting factors: Three factors were recognized as limiting. They included: (a) the high frequency of ship traffic in the channel; (b) the steep and rocky coastline; and (c) the budget of the MBES survey.

Data Gathering: The MBES survey was performed with an integrated measurement system which consisted of six main components:

(1) WASSP S3 multibeam wideband sounder c/w DRX (Figure 4)

(2) WASSP sensor box with integrated spatial IMU

(3) Hemisphere V320 GNSS smart antenna (mFreq, mGNSS, RTK, SBAS)

(4) accumulator and power cord

(5) configuration computer and cable

(6) configuration software (PoketMax, NtripClient, DRX Setup Webpages)

(7) software for guidance (CDX) and data export (Data Manager) 

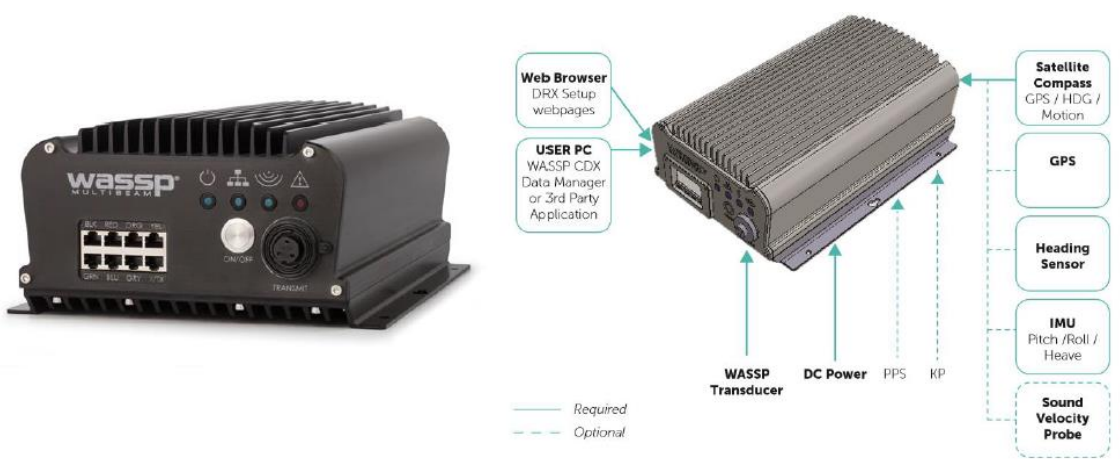

Figure 4. The WASSP S3 multibeam wideband sounder.

The spatial reference of all MBES sensors is paramount to obtaining high-quality data. Therefore, the MBES system was mounted and configured according to the manufacturer's instructions and international standards. The WASSP S3 is a cost-effective, mid-level, multi-purpose multibeam sounder, released in 2016, which bridges the gap between singlebeam and higher priced MBES systems. It allows the exploration, high-resolution model generation, and detailed mapping of the seabed, lakes, and rivers. The S3 version is the third and latest generation of multibeam depth gauges that use broadband technology. The S3 features the IDRX-32 processor with a high-frequency transducer WMB-160 [69]. Therefore, this MBES system was chosen for all of the above-mentioned reasons and because it was the only MBES device available to the research team. Detailed device specifications are presented in Table 1.

Table 1. The basic specification of the WASSP S3.

\begin{tabular}{|c|c|c|c|}
\hline \multicolumn{4}{|c|}{ PHYSICAL PROPERTIES OF TRANSDUCER HEAD } \\
\hline Length (m) & 0.5240 & & \\
\hline Width (m) & 0.1665 & & \\
\hline Height (m) & 0.0856 & & \\
\hline Weight (kg) & 15 (cable dependent) & & \\
\hline \multicolumn{2}{|c|}{ SYSTEM PARAMETERS } & $\begin{array}{c}\text { SYSTEM } \\
\text { PARAMETERS }\end{array}$ & \\
\hline Min. frequency $(\mathrm{kHz})$ & 120 & Transceiver type & DRX-32 \\
\hline Max. frequency $(\mathbf{k H z})$ & 200 & $\begin{array}{l}\text { Transducers } \\
\text { supported }\end{array}$ & WMB-160 \\
\hline Number of selectable frequencies & 80 & IMU supported & External \\
\hline Min. depth (m) & 1 & Depth-Swath * & $200 \mathrm{~m}$ \\
\hline Max. depth (m) & 380 & Effective beamwidth & $120^{\circ} \times 4^{\circ}$ \\
\hline Depth resolution (mm) & 20 & $\begin{array}{l}\text { Beam spacing } \\
\text { (nominal) }\end{array}$ & $0.54^{\circ}$ over $120 \mathrm{o}$ \\
\hline Max. swath as a function of depth & 3.5 & Sensor connectivity & DRX \\
\hline Min. beam width across track (deg) & 3.6 & PSU & 9-32VDC (30W) \\
\hline Min. beam width along track (deg) & 2.6 & Tide correction & Yes \\
\hline Interface & RS232/422/NMEAO183 & $\begin{array}{l}\text { Operating } \\
\text { temperature }\end{array}$ & $0^{\circ} \mathrm{C}$ to $50{ }^{\circ} \mathrm{C}$ \\
\hline
\end{tabular}

* The depth capability was subject to a variety of external factors.

The CDX is the operating system used by the WASSP to control, visualize, and manage the collected data. It allows you to map the seabed in high resolution and to display the recorded area in real time on a simplified user interface. The CDX consists of six components: (1) home access, which provides configuration options for the screens, panels, layouts, tools, system setup, and user settings; (2) screen frames, which are associated with certain types of data for visualization and control; (3) CS (context sensitive) menu, which allows the setting and configuration of specific display panels that can be accessed by right- 
clicking on any panel; (4) information screen, which has the ability to overlap information on the display panel with the CS menu; (5) control tools, which allow you to control the overlap of the control panel on the screen; (6) optional tools, which are used to display general data.

The database is multi-resolution and organized in such a way that as your scale becomes larger, the spatial resolution of the model increases [70]. The system is equipped with advanced components that provide real-time insight into the visual quality of the model through five views of the recorded area: (a) two-dimensional; (b) perspective (3D); (c) sonar field; (d) side scan; and (e) profile (Figure 5). Data Manager is a software package for data management that has three basic functions: (1) data recording; (2) display; and (3) data export.

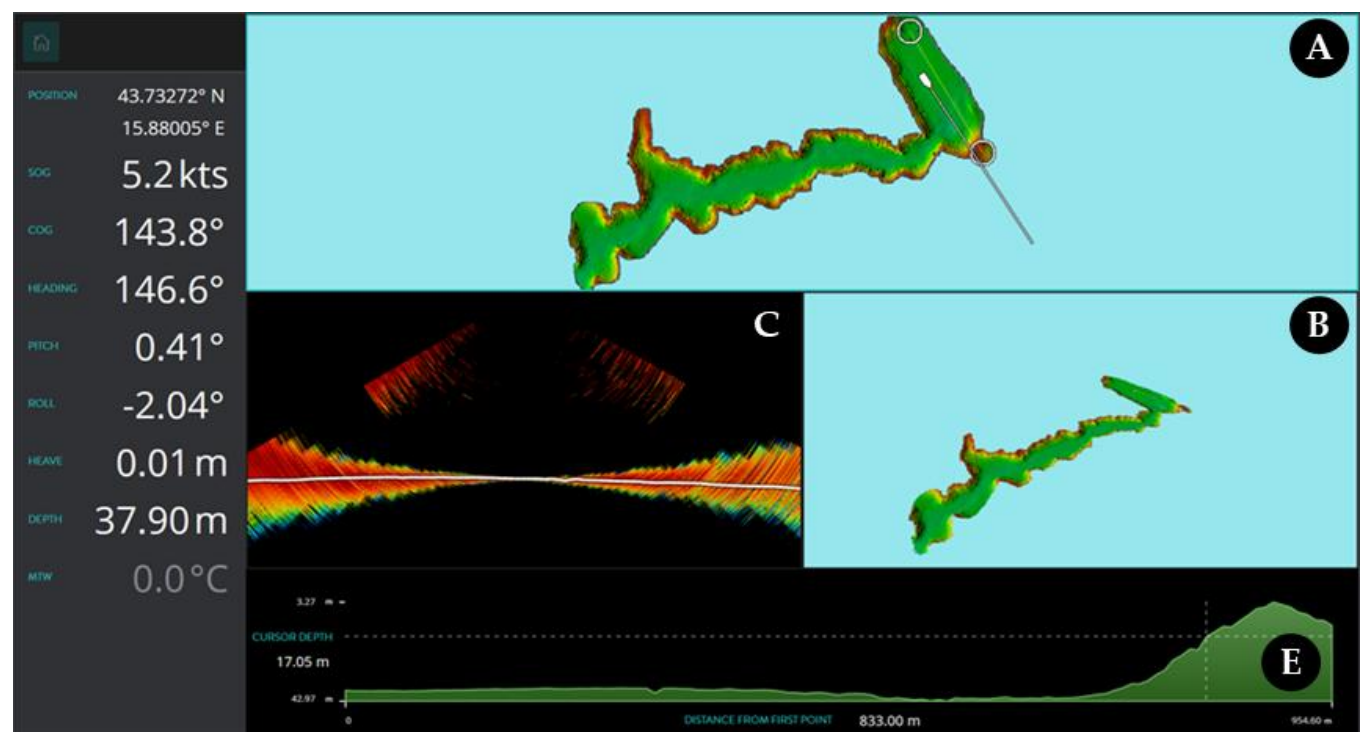

Figure 5. The views of the recorded area: (A) two-dimensional; (B) perspective (3D); (C) sonar field; (E) profile.

The $W M B-160$ transducer with an operating frequency of $160 \mathrm{kHz}$ was used in the bathymetry of the St. Anthony Channel. It was firmly attached to a steel rod to prevent its movement and negative impact on output results. The WMB-160 was immersed in water to a depth of $60 \mathrm{~cm}$ (Figure 6). The difference in depth between the device and the water surface was included in the measurement. The reference mean sea level was determined using geodetic measurement (GNSS-RTK receiver STONEX S10) in front of the Institute for Marine and Environmental Research of the Ruđer Bošković (RBI), marine station in Martinska. The reference mean sea level was recognized as the point marked by wet conditions, a difference in color, and algae formed on the concrete pier in front of the Martinska station. This represented the average level of the water for the research area. A similar example of measuring the mean sea level using a GNSS-RTK receiver was presented by [71].

The WMB-160 was oriented at an angle of $90^{\circ}$ in relation to the boat so that the sound signal could travel the shortest path to the seafloor. It was placed at an appropriate distance from the external marine engine in order to reduce the impact of turbulence on the quality of the collected data.

The Hemisphere V320 GNSS smart antenna was mounted just above the WMB-160 transducer (Figure 6). This GNSS receiver was chosen for several reasons. The Hemisphere Vector V320 is a multi-frequency, multi-constellation GNSS antenna based on Eclipse Vector ${ }^{\mathrm{TM}}$ GNSS technology, which provides an RTK level position and precise heading (Hemisphere GNSS, 2015) for marine and land applications. It achieves a heading accuracy of up to $0.17^{\circ} \mathrm{RMS}$ (depending on the environmental conditions) and offers a robust positioning performance [72]. Details of the key features of the Hemisphere V320 GNSS smart antenna are available from [72]. The Hemisphere Vector V320 was connected to the CROPOS (Croatian 
Positioning System) via the GSM network. The CROPOS system consists of 33 reference GNSS stations located a distance of $70 \mathrm{~km}$ from each other and arranged so as to cover the entire territory of Croatia for the purpose of collecting satellite measurement data and calculating correction parameters. The purpose of CROPOS is to enable real-time positioning with an accuracy of $\pm 2 \mathrm{~cm}$ in the horizontal direction and $\pm 4 \mathrm{~cm}$ in the vertical direction throughout the country [73]. The MBES data were collected using the WGS84 geographic coordinate system. Detailed GNSS sensor specifications are presented in Table 2 [72].

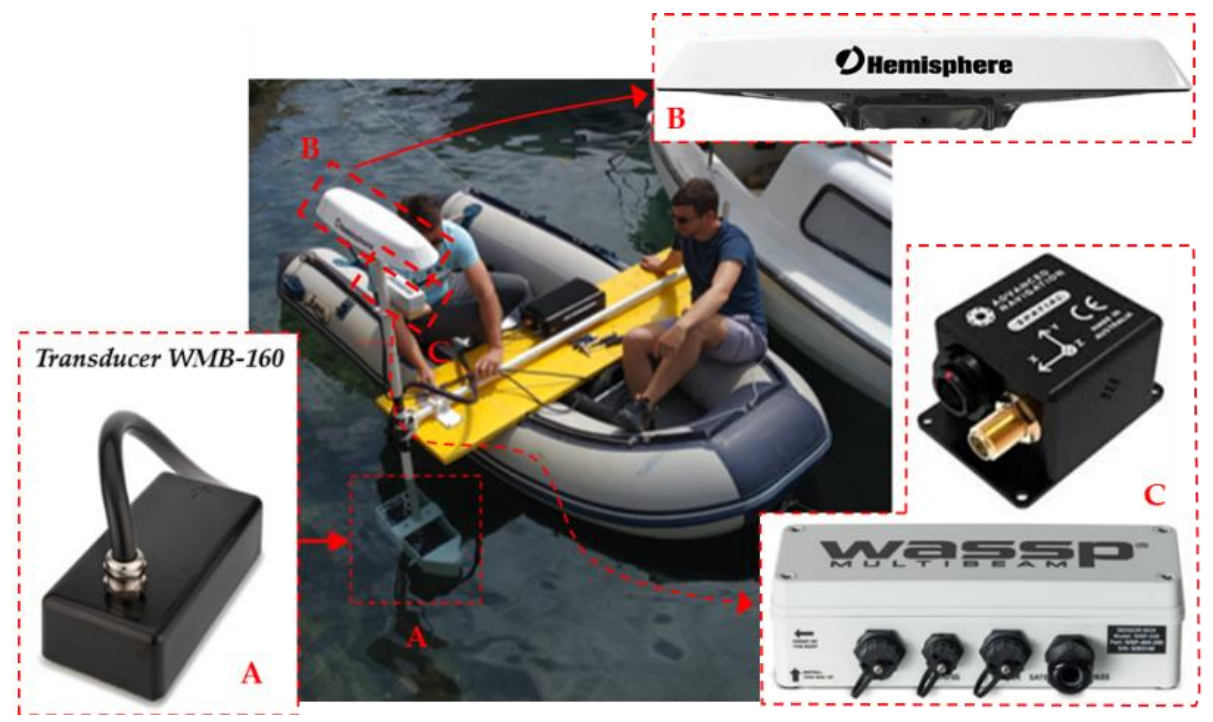

Figure 6. (A) The WMB-160 transducer, (C) the WASSP sensor box with integrated advanced navigation spatial IMU WSP002-INU and the (B) Hemisphere V320 GNSS Smart Antenna.

This inertial navigation package consisted of a Hemisphere V103 satellite compass, the WASSP WSP-038 INU (Internal Navigation Unit), and a waterproof junction box. The WSP-038 INU, located in a waterproof junction box, is an extremely compact and highly sensitive multi-axis motion sensor that works in unison with the compass to provide rock solid pitch, roll, heave, and yaw compensation for any boat size [72]. This navigation package is ideal for small vessels that can be heavily affected by waves hitting the front and side. In order to minimize the error, the source sensors were calibrated at the beginning of the survey (roll, pitch, time, and heading offsets) and regularly checked during the survey [23]. The following are examples of other MBES surveys, and an overlap of around $40 \%$ between survey lines was held with the aim of avoiding the influence of bad quality external beams $[23,74]$.

The vessel central reference point (CRP) was determined upon MBES installation to best suit the vessel balance. The defined settings (beam aperture, pulse length, beam spacing) were controlled by the onboard software and remained constant during the MBES survey. The sound velocity (SV) was derived from the direct seawater temperature $\left({ }^{\circ} \mathrm{C}\right)$ and salinity (ppt) data. The seawater temperature and salinity data were measured using the EXO2 Multiparameter Sonde [75]. This device is used when seawater properties are known (measured) in order to derive the sound velocity in DRX. The SV parameter is the key in compensating for range inaccuracies caused by sound speed variations. It is regarded as one of the key factors that can affect the quality of MBES data. Furthermore, the calculated SV was checked using a sonar field device (Figure $7 \mathrm{~b}$ ), that is a visual component on the CDX interface above a flat seabed around $12 \mathrm{~m}$ deep. The visual effect of an incorrect SV is manifested by the concave or convex curvature of the flat seabed (Figure 7a) [76,77]. Depending on the location, the SV was adjusted and manually checked regularly using a sound display. 
Table 2. The GNSS sensor specifications.

\begin{tabular}{|c|c|}
\hline Receiver Type & Vector GNSS L1 Compass \\
\hline Signals received & GPS and GLONASS \\
\hline Channels & 502 \\
\hline GPS sensitivity & $-142 \mathrm{dBm}$ \\
\hline SBAS tracking & 3-channel, parallel tracking \\
\hline $\begin{array}{l}\text { Update rate } \\
\text { timing (1 PPS) }\end{array}$ & $10 \mathrm{~Hz}$ standard, $20 \mathrm{~Hz}$ optional \\
\hline Position accuracy: Single point & RMS (67\%) $1.2 \mathrm{~m} ;$ 2DRMS (95\%) $2.5 \mathrm{~m}$ \\
\hline Position accuracy: SBAS (WAAS) & RMS (67\%) $0.3 \mathrm{~m} ; 2 \mathrm{DRMS}(95 \%) 0.6 \mathrm{~m}$ \\
\hline Position accuracy: Code differential GPS & RMS (67\%) $0.3 \mathrm{~m} ; 2$ DRMS (95\%) $0.6 \mathrm{~m}$ \\
\hline RTK & $\begin{array}{c}\text { RMS }(67 \%) 10 \mathrm{~mm}+1 \mathrm{ppm} ; 2 \mathrm{DRMS}(95 \%) \\
20 \mathrm{~mm}+2 \mathrm{ppm}\end{array}$ \\
\hline Heading accuracy (RMS) & $<0.17^{\circ}$ \\
\hline Heave accuracy (RMS) & $<30 \mathrm{~cm}$ (DGNSS), <10 cm (RTK) \\
\hline Pitch/Roll accuracy & $<1^{\circ}$ RMS \\
\hline Timing (1 PPS) accuracy & $20 \mathrm{~ns}$ \\
\hline Rate of turn & $100^{\circ} / \mathrm{s}$ maximum \\
\hline Heading fix & 10 s typical (valid position) \\
\hline Maximum speed & 1850 mph (999 kts) \\
\hline Differential options & SBAS Beacon, External RTCM \\
\hline \multicolumn{2}{|l|}{ L-Band Receiver Specifications } \\
\hline Receiver type & Single channel \\
\hline Channels & 1530 to $1560 \mathrm{MHz}$ \\
\hline Sensitivity & $-130 \mathrm{dBm}$ \\
\hline Channel spacing & $5 \mathrm{kHz}$ \\
\hline Satellite selection & Manual or Automatic \\
\hline Reacquisition time & $15 \mathrm{~s}$ (typical) \\
\hline
\end{tabular}
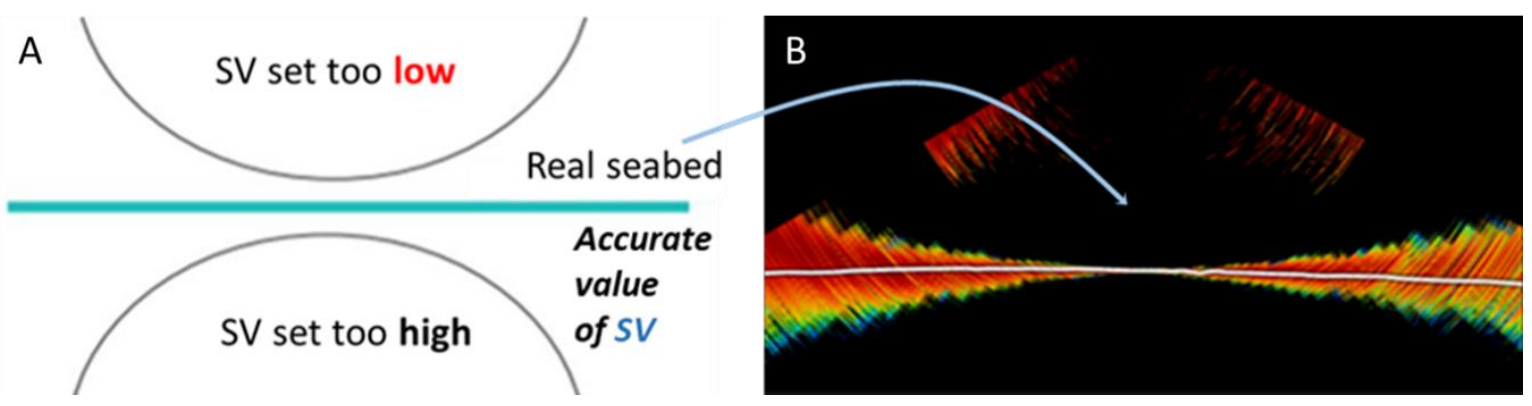

Figure 7. An example of: (A) the inaccuracies of the seafloor display due to incorrect SV; (B) an accurate value of SV.

An important phase of the system calibration process was the configuration of the GPS antenna, for which the PocketMax3 software was used (Figure 8). The antenna was connected to the CROPOS_VRS_RTCM31 system via NTRIP Client software, which enables real-time data registration. 


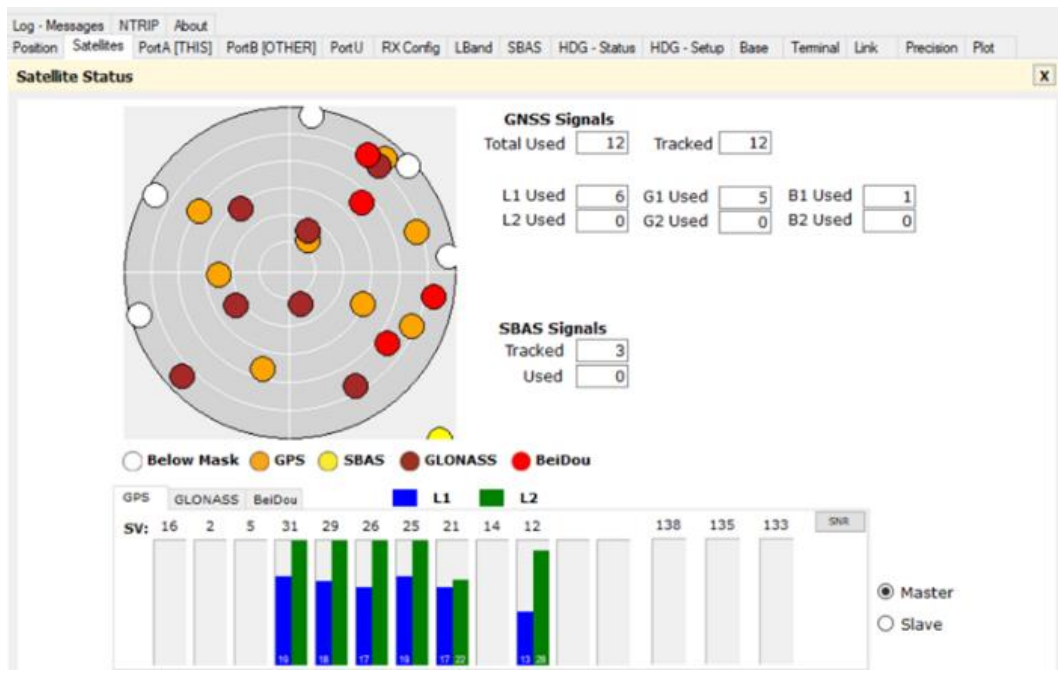

Figure 8. The system calibration in PocketMax3 software.

A total of $2563 \mathrm{~km}$ linear kilometers of high-resolution MBES data, along with backscatter (BS) data, was collected, which covered the St. Anthony Channel. The Luna sailed with a reasonably constant speed (mean speed: 5 knots) (Figure 9) despite heavy ship traffic. At greater depths, the survey speed was lower in order to capture the required resolution. The ping (sound pulse) rate during the MBES survey was around 10 to $14 \mathrm{sec}$, while the operating beam width was $20^{\circ}$.

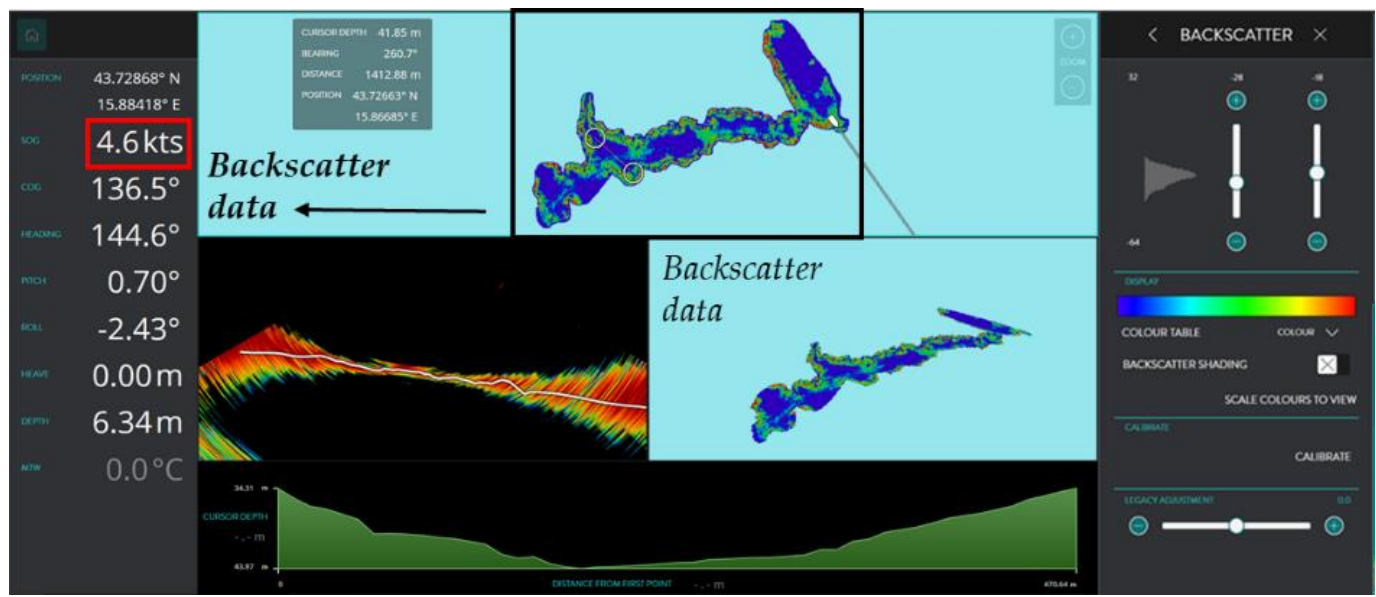

Figure 9. The collected backscatter data with the indicated speed of the Luna boat.

\subsection{Data Processing}

Point Filtering in CloudCompare (CC)

The measured data were transferred to the workstation for further processing via the CDX and Data Manager software packages. The software packages create a separate file with information about the position of the points, the time at which the points were registered, the depth, and the hardness of the seafloor. Hardness is one of the seafloor features that enables its classification. Hardness is determined based on backscatter intensity. For example, harder seafloor types (e.g., rocks, gravel) reflect more sound than softer seafloor types (e.g., mud, silt). These software packages only have the ability to export points in the .xyz format. Due to the structure, density, and number of samples, this format is not suitable for the further processing, analysis, visualization, and interpretation of data. Therefore, all points within the ArcMap software package were converted to the las format using the LAStools for LiDAR processing. Then, all converted data were transformed in the projection 
reference system HTRS96/TM. The resultant datasets (point clouds), reconstructed from the MBES survey, contained a specific proportion of errors. The majority of them were outlier noise, clustered in steep slope areas. Semi-automatic point processing was performed through the following steps (Figure 10). Some of the steps are statistical point-based filter techniques developed using the Point Cloud Library (PCL) and implemented in the CloudCompare [78]:

(1) Manual segmentation of the point cloud;

(2) Manual filtration using the $3 D$ display and profile views;

(3) SOR (Statistical Outlier Removal) filter;

(4) Segmentation method (LabelConnected components);

(5) CSF (Cloth Simulation Filter) method.

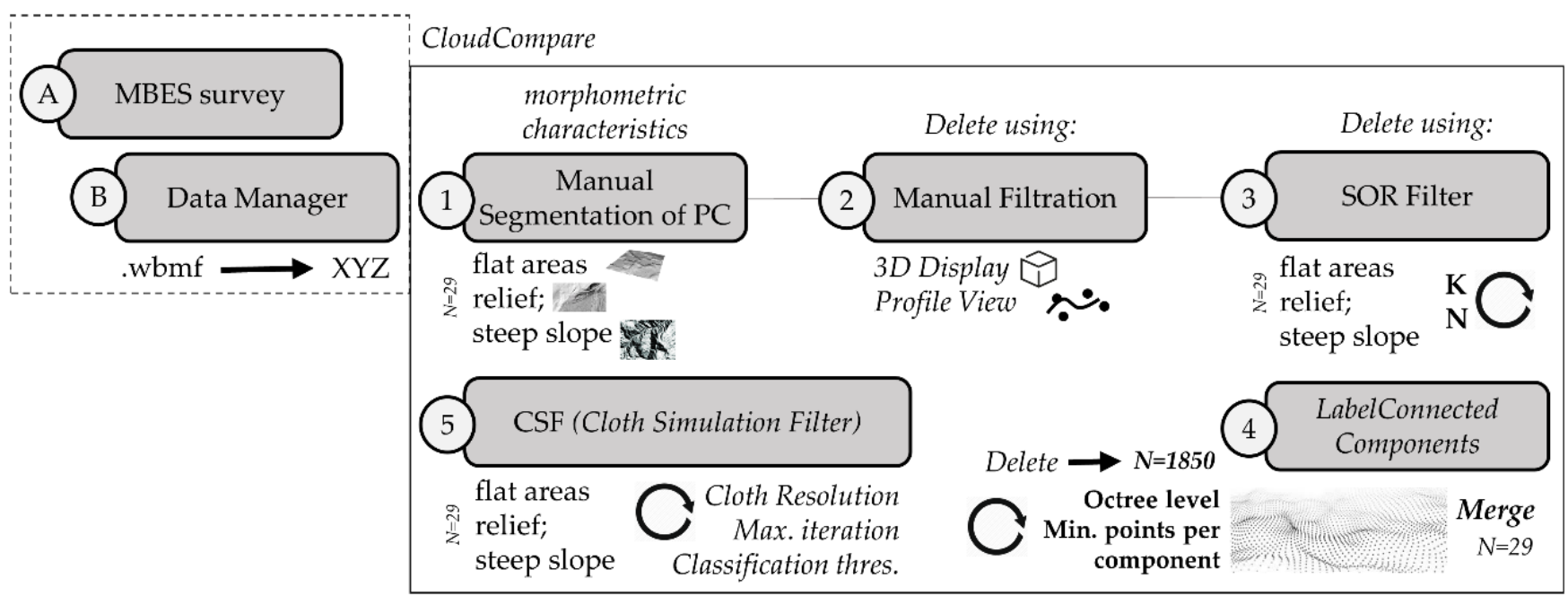

Figure 10. A proposed new and user-friendly framework for MBES point filtering in CloudCompare.

\section{Manual Segmentation of the MBES Point Cloud}

The manual segmentation of the point cloud was carried out following the morphometric characteristics of the seafloor. The criterion for manual segmentation was the vertical ruggedness of seafloor assessed visually using a $2 \mathrm{D}$ perspective view and profile representation of the recorded data that were visible on the CDX software. On the basis of a preliminary CDX map, a total of 29 areas or point clouds were extracted using the CloudCompare software. These point clouds were classified into three classes: (a) flat areas (which included the biggest proportion of the point cloud); (b) relief; and (c) steep slope (which referred to the most complex, edges of the coast).

\section{Manual Filtration Using the 3D Display and Profile View}

The manual filtration method is an extremely time-consuming and demanding process in which the user removes outliers from 3D views and longitudinal and transverse profiles by following the dominant terrain configuration. Therefore, only those points that deviated significantly from the point cloud were removed. Manual filtering using the 3D display and profile view was performed for each extracted point cloud. The manual filtration was carried out with the aim of facilitating the selection of appropriate statistical parameters within the Statistical Outlier Removal (SOR) filter and LabelConnected components.

\section{SOR (Statistical Outlier Removal) Filter}

This tool is often used to filter outlier data [56,79-83]. In the third step, an advanced SOR filter (Statistical Outlier Removal) was used. This is statistical point-based filter technique was developed using the Point Cloud Library (PCL) and implemented in the CloudCompare software $[78,79]$. It assumes that distance between a given point and its neighbors 
is normally distributed [84]. First, it computes the average distance (riK) of each point $(\mathrm{pi}=1 \ldots n)$ in a dataset from its neighbors through the $k$-nearest neighbors $(\mathrm{KNN})$ searching function [85]. This value is assessed using the sigma rule (standard deviation multiplier threshold-nSigma), which represents the standard deviation multiplier [84]. So, points are considered as outliers if they are farther than the $\mathrm{n}$ standard deviations from the mean. The default parameters in the tools are $\mathrm{k}=6$ and $n=1$. This filter was used for each extracted point cloud $(n=29)$. An iterative process was performed in a similar manner to other examples $[80,82,83]$, with the aim of selecting the most appropriate parameters based on subjective opinion and knowing that the values should be adjusted according to the specific characteristics of the recorded scene. We sought to achieve a reduction in the number of noise points and to maintain the seafloor geometry.

\section{LabelConnected Components}

Prior to the automatic segmentation process, the refined point clouds $(n=29)$ were merged. Then, the segmentation method was conducted using the LabelConnected components tool [86]. This tool segments the selected cloud(s) into smaller parts separated by a minimum distance. The tool requires the setup of an octree level parameter, which uses a 3D grid to extract the connected components. By selecting the octree level, you can define the minimum gap between two components (a higher level means smaller gap) [87]. This value depends on the total number and density of points collected. In this case, 11 was recognized as an adequate number. The next parameter refers to the minimum points per component. This is also conditioned by the number and density of collected points, and it was defined that all components that have fewer than 5 points were excluded. Finally, the random colors option was highlighted, which assigns a random color to each component to make it easier to spot differences between the components. An iterative process was performed with the aim of selecting the most appropriate parameters based on subjective opinion [86,88]. In the final step, after the segmentation, the user decides whether derived point clusters are noise or not [88]. All smaller segments that were generated (point clusters) were recognized as noise and deleted. After deleting these smaller point clusters, only one large point cloud remained, which represented the St. Anthony Channel. It was re-divided into 29 smaller segments using the polygon boundaries from chapter Manual Segmentation of the MBES Point Cloud in order to facilitate the selection of appropriate user-defined parameters for the next step.

\section{CSF (Cloth Simulation Filter) Filter}

In the next step, the CSF (Cloth Simulation Filter) tool was used. Its parameters are few and easy to set [89]. Recent research has shown the applicability of the CSF in seafloor point segmentation [90]. It is primarily intended for use with an extract of ground points in discrete return LiDAR point clouds. The basic principle of the tool is that cloth covers a point cloud that is turned upside down and then, by analyzing the interactions between the nodes of the cloth and the point cloud, the final shape of the cloth is determined and used as a reference base to classify the original points into ground and non-ground points [91]. The main reason for the application of this tool was the emergence of artifacts conditioned by the characteristics of the equipment and the morphology of the seafloor. Figure 11 shows an example of such a sound refraction artifact [92,93], which we called a false mirror seafloor. They are usually present in a MBES survey [94]. 


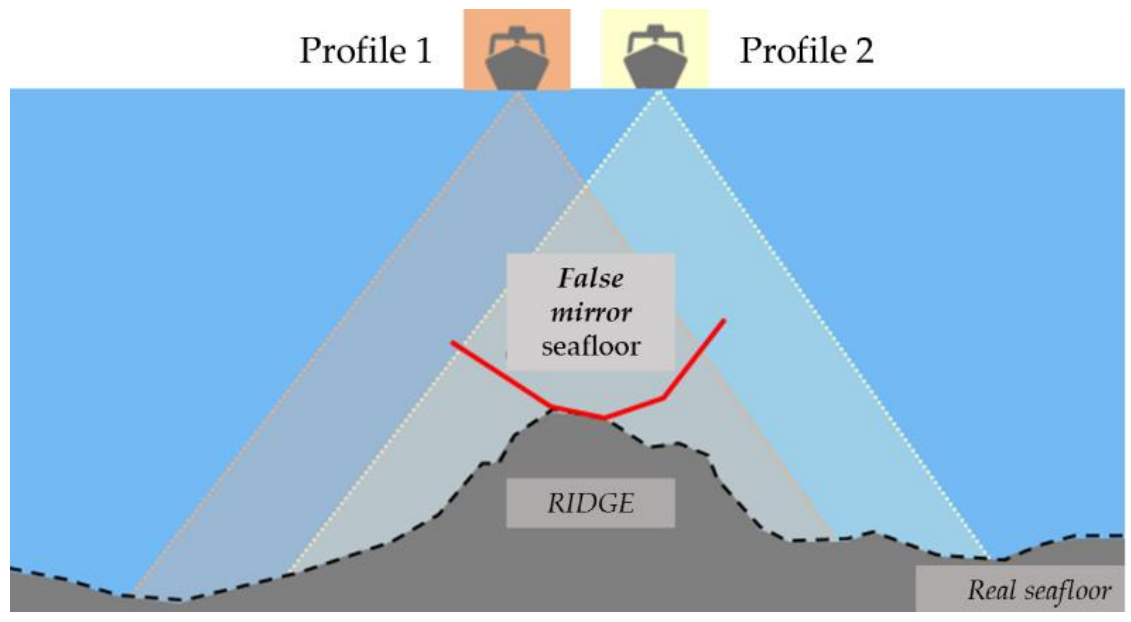

Figure 11. An example of the false mirror bottom artifact formation.

The general and advanced parameters need to be set by the user. Advanced parameters include cloth resolution, max iterations, and classification threshold. Cloth resolution refers to the grid size of cloth that is used to cover the terrain. Max iterations refer to the maximum iteration times of the terrain simulation. Classification threshold refers to a threshold to classify the point clouds into the ground and non-ground points based on the distances between the points and the simulated terrain [95]. Since the CSF has a filtering option for three terrain types (flat terrain, steep terrain, and high and steep slopes), default parameters were first used for point cloud clusters $(n=29)$ that were extracted following the morphometric characteristics of the seabed. However, visual observations revealed that these default parameter values did not produce satisfactory results. An iterative process was performed with the aim of selecting the most appropriate parameters based on subjective opinion. For point clusters classified as flat areas, the parameters were 0.5 for cloth resolution, 500 for maximum iteration, and 0.1 for classification threshold. For clusters classified as relief, the parameters were 0.2 for cloth resolution, 500 for maximum iteration, and 0.1 for classification threshold. For clusters classified as steep slopes, the parameters were 0.1 for cloth resolution, 500 for maximum iteration and, 0.1 for classification threshold. After filtering, all point clusters were merged into one point cloud.

Creation of an Integrated Model of the St. Anthony Channel

For the derivation of the integral model of the St. Anthony Channel, a filtered MBES point cloud and a point cloud derived from UAV photogrammetry were used. The UAV dense point cloud was generated following the image workflow process in Agisoft Metashape 1.5.1 (Figure 12). The workflow process included six steps, which are very well-known in the SfM photogrammetry process and performed in Agisoft Metashape. After the alignment, a sparse cloud was generated. It was used to determine which UAV photos were overlapping (it had a satisfactory number of valid tie points). Then, using the stereo pairs with known distortion parameters and camera position, the UAV dense point cloud was generated and exported into the desired format. 


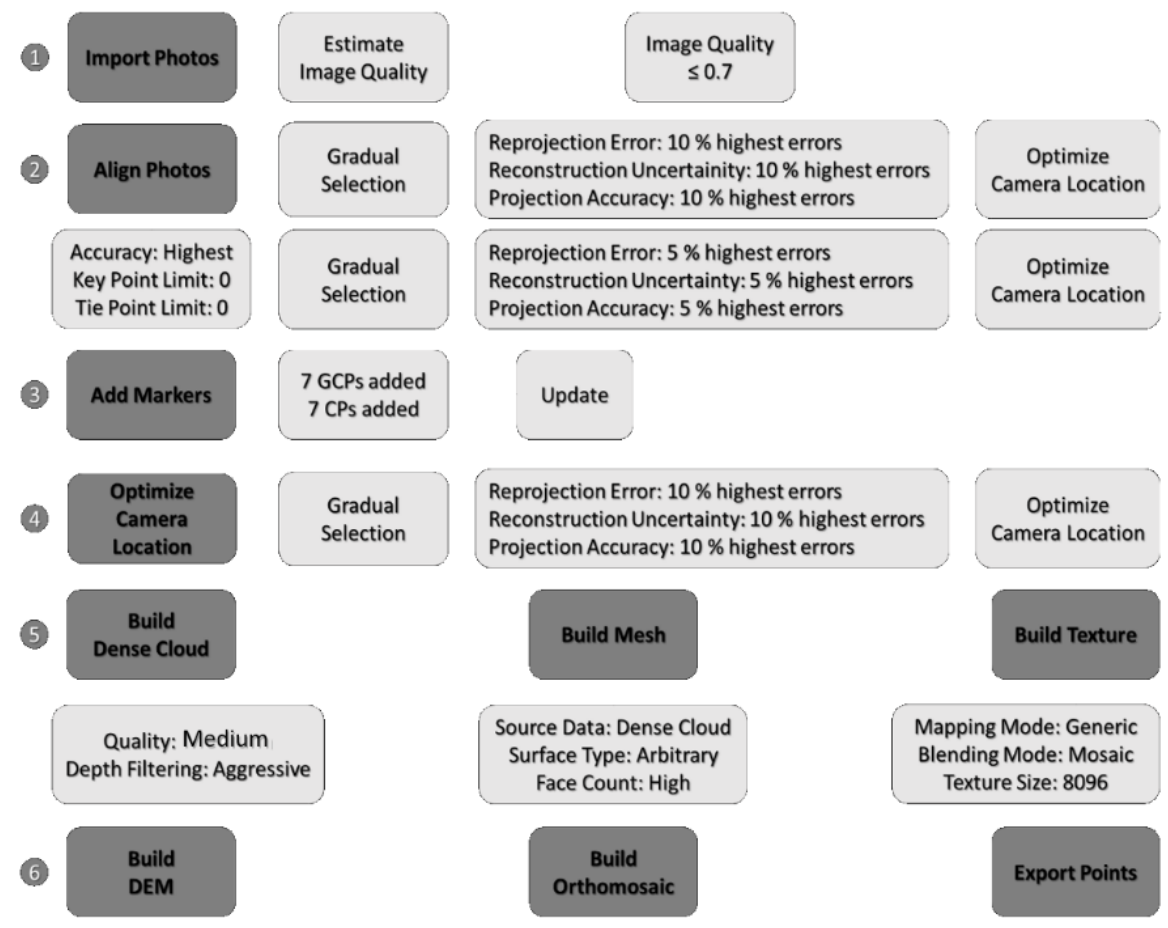

Figure 12. The image workflow process.

The mentioned point clouds (UAV and MBES) were converted into LAS format using LAStools. In ArcMap, they were merged into one point cloud which represented the wider area of the St. Anthony Channel. Using the LAS Dataset to Raster tool from the created LAS Dataset, an integrated model of the St. Anthony Channel was generated. The binning approach was used, which provides a specific cell assignment method to determine each output cell using the points that fall within its range, along with a void fill method to determine the value of the cells that do not contain any LAS points. The nearest cell assignment method was selected. It used the nearest neighbor assignment to determine the cell value. The natural neighbor void fill method was also used. This uses the natural neighbor interpolation method (IM) to determine the cell value. The natural neighbor is one of the most popular IMs with wide applications [96]. After the selection of the best interpolation method, the next step involved the determination of the optimal spatial resolution. This was a complex question because the spatial resolution of the DBM should vary systematically with the depth, obliquity, sonar design characteristics, and user-defined parameters, such as mode, speed, and angular sector. However, most DBMs utilize fixed grid spacing from which the geomorphometric parameters are derived [97]. The spatial resolution was calculated using the grid calculator and point pattern method [98], i.e., the distance between the sampled points. The optimal spatial resolution of $50 \mathrm{~cm}$ was selected. It represented a compromise between the sampling density of the height and depth points and the recorded surface. For visualization purposes, the spatial resolution was reduced to $100 \mathrm{~cm}$.

\section{Results}

\subsection{UAV Photogrammetry}

In total, within the entire area of the St. Anthony Channel, 6003 high-quality photographs were collected. The DOP, DSM, and PointCloud were extracted. The dense point cloud was used in the production of the integrated model (UAV data and MBES data) of the St. Anthony Channel. The quality parameter within the Build Dense Cloud option, which affects the spatial resolution of the DEM, was set to medium quality. Figure 13 shows part of the generated DSM of the right-hand coastline of the St. Anthony Channel. 


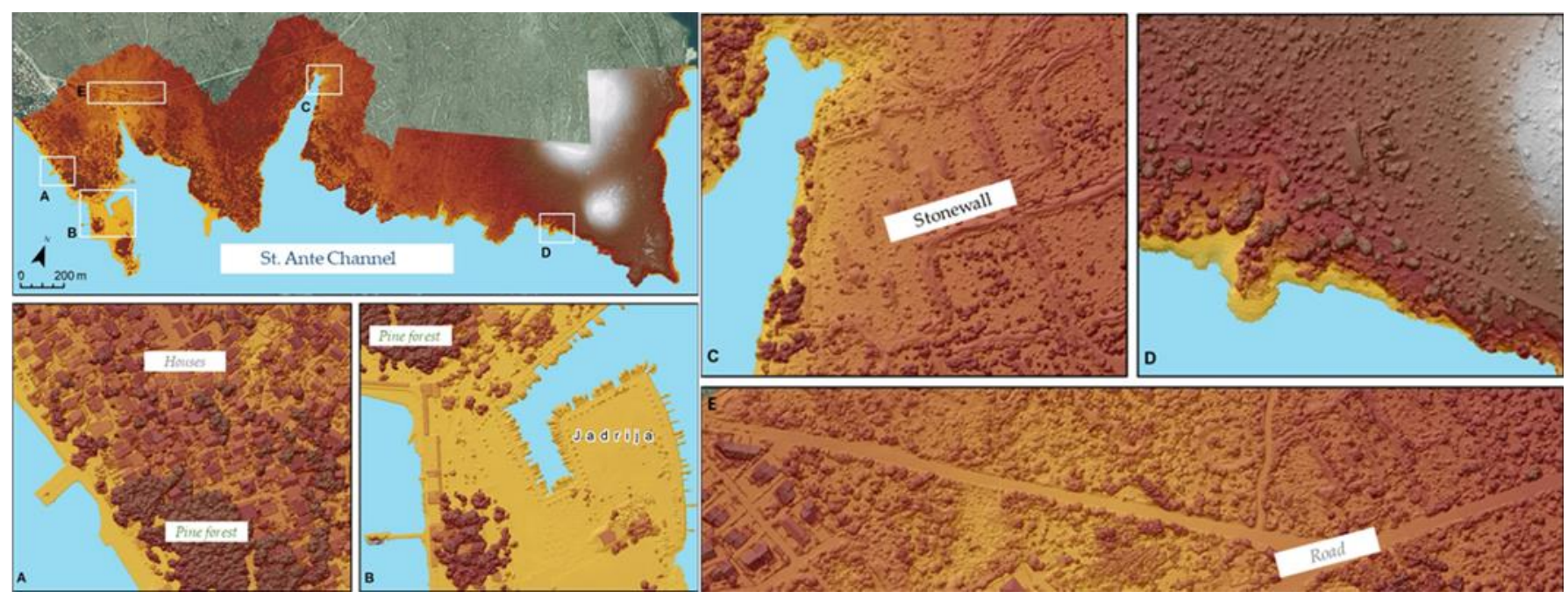

Figure 13. A section of the generated DSM of the St. Anthony Channel.

\subsection{Post-Processing Results of Acquired MBES Dataset}

At the end of the MBES survey, a total of 15,478,587 points were collected, which were stored in 28 WPF documents. The minimum collected depth value in these unfiltered dense point clouds was $-1.07 \mathrm{~m}$, while the maximum depth was $-83.26 \mathrm{~m}$. The maximum value was an outlier caused by the measurement system. In the following text, the results after the implementation of the suggested methodological process are described.

(1) The manual segmentation of point cloud; and

(2) Manual filtration using the 3D display and profile view.

The 29 point cloud segments were extracted from the initial dense point cloud using the CloudCompare software. These point clouds were classified into three classes: (a) flat areas; (b) relief; and (c) steep slopes. Then, within each segment the outliers were manually deleted using the 3D display and profile view. A total of 14,041 points were deleted. Therefore, in 29 point cloud segments, a total of 15,464,546 points remained.

\section{(3) SOR (Statistical Outlier Removal) filter.}

The SOR filter was used for each extracted point cloud $(n=29)$. The most appropriate SOR parameters based on subjective opinion were selected. A total of 673,432 points were deleted. Therefore, in 29 point cloud segments, a total of 14,791,114 points remained. The reduction percentage after the denoising process was $4.35 \%$. Then, the filtered point clouds $(n=29)$ were merged into one dense point cloud.

\section{(4) Segmentation method (LabelConnected components).}

This function was used because it segments a point cloud into compact sub-clouds via octree. The result of this step was the segmented blocks of the dense point cloud, which had certain characteristics with regard to the selected parameter settings. A total of 1850 smaller components were extracted (Figure 14). Those smaller components that deviated from the reference point cloud of the St. Anthony Channel were inspected and deleted. The point clouds that represented noises and errors generated in the data collection process were marked and removed from the set of points using the delete option. This tool has been shown as being very useful in the easy removal of isolated points and outliers. In those smaller components, a total of 321,432 points were deleted. Therefore, a total of $14,469,682$ points remained. The reduction percentage after the denoising process was $2.17 \%$. Before the next step, the large point cloud, which represented the St. Anthony Channel, was re-divided into 29 smaller segments using the polygon boundaries from subsection Manual Segmentation of the MBES Point Cloud in order to facilitate the selection of the appropriate user-defined parameters in the CSF method. 


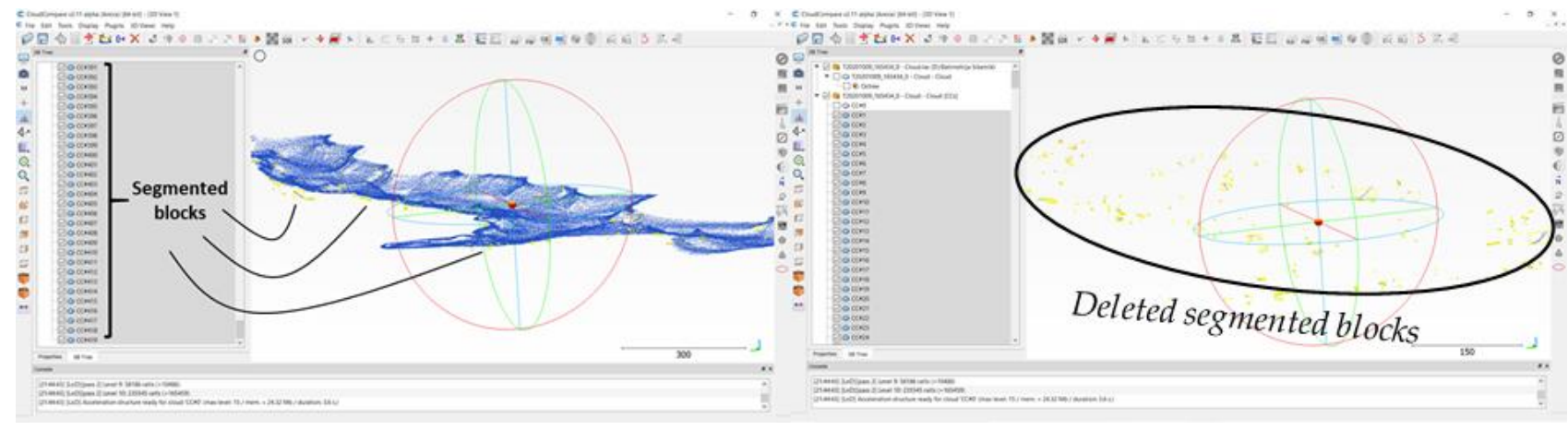

Figure 14. An example of dense point cloud filtering using the segmentation method (LabelConnected components).

\section{(5) CSF (Cloth Simulation Filter) method.}

Since the CSF has a filtering option for three terrain types (flat terrain, steep terrain, and high and steep slopes), different parameters were used for the 29 point cloud segments that were divided into the three classes mentioned in 2.2.1.1. After filtering all point clusters, a total of 1,175,315 points were deleted (Figure 15). Therefore, a total of 13,294,367 points remained, which represented the final number of points. After filtration, the maximum depth in the point cloud was $-49.48 \mathrm{~m}$. The reduction percentage in points after the denoising process was $14.11 \%$. In other studies, this percentage has varied significantly from less than $1 \%$ to over $25 \%$ [8]. In this study, an approximate mean of that range was obtained. The high variability can be explained by the different types of sensors used in bathymetry surveys, the high variability of environmental conditions, and the characteristics of the seabed. The purpose of the dataset can also affect the number of detected outliers. Namely, in the context of nautical charting, small sounding values are often kept in a dataset in order to ensure the safety of navigation [8].

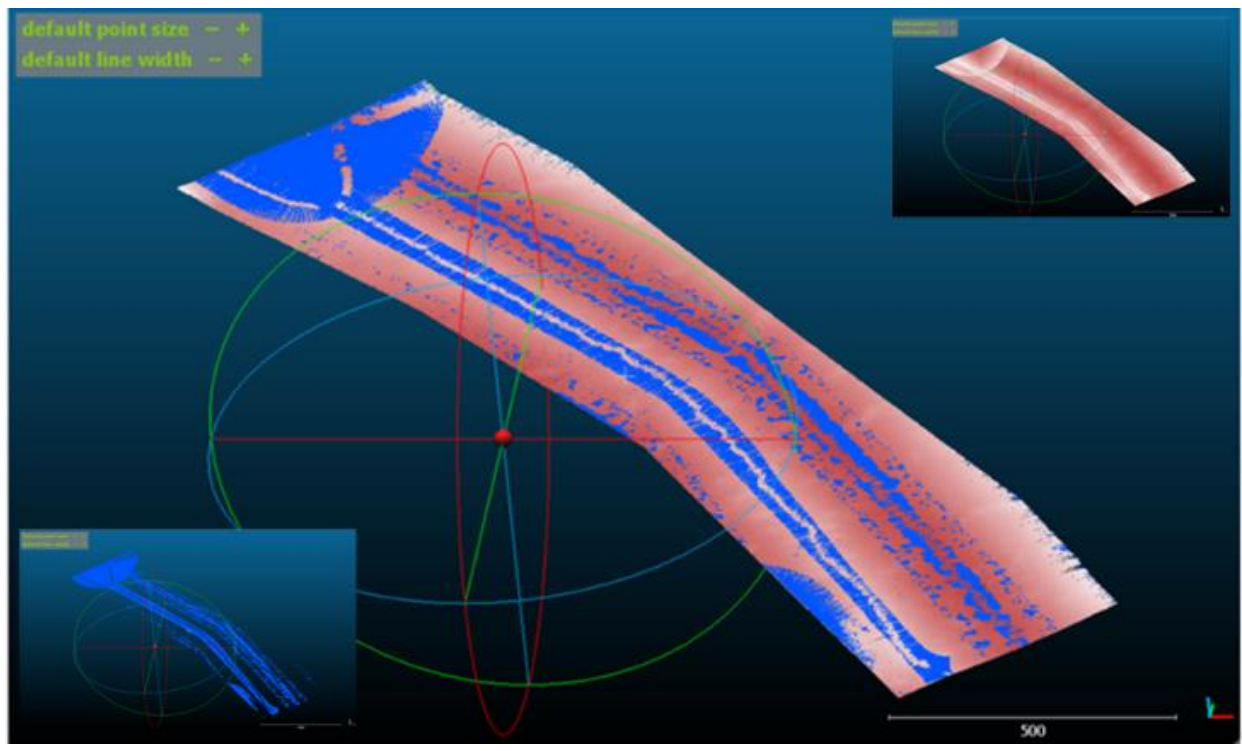

Figure 15. An example of filtering using the CSF method.

Through MBES dense cloud point filtration, three dominant types of noise were observed, which was similar to [54]. They included: (a) points that appeared below and above the seabed; (b) points that referred to physical objects, such as schools of fish; and (c) structural noise (Figure 11). However, it should be stated that the efficiency of this user-friendly semi-automatic approach of MBES point cloud filtering will primarily depend 
on the proportions of the types of error within the recorded dense point cloud and the characteristics of the recorded seabed. As mentioned by [54], the main problem with the removal of these types of noise is that you typically also find features on the seafloor that are important for users but cannot be easily distinguished from noise (e.g., pipelines or a steep-sided valley). This user-friendly and almost fully-automated approach for point cloud post-processing will handle the first type of noise very effectively. The effectiveness of the cleaning of the second type of noise will primarily depend on the determined size of the local neighborhood (user-defined parameters). A sufficient amount of real data points (clean seabed) needs to be included in a neighborhood in order to effectively clean the outliers. Therefore, as stated in [61], we believe that it is necessary to collect MBES data as densely as possible in order to produce statistically robust estimates of the depth and use the consistency of the data to identify errors. fMBES sensors and related procedures have advanced so much that they acquire most of the data in the correct manner most of the time [61]. The validation method used to evaluate the performances of the proposed approach included the visual inspection of the DBM [8] to make sure that the most conspicuous outliers were removed.

\subsection{Integral (MBES and UAV) Model of the St. Anthony Channel}

From the point clouds generated by the UAV photogrammetry and MBES, the first integral high-resolution depth and elevation model of the wider area of the St. Anthony Channel was created (Figure 15). The created output thematic map is a combination of a topographic and bathymetric map. In this model, the maximum depth of the seafloor generated from the filtered MBES dense point cloud was $-49.48 \mathrm{~m}$, while the maximum elevation within the UAV recorded area was $66.36 \mathrm{~m}$. The derived integral model was 3D visualized using the stretch classification method (Figure 16B), which is ideal for displaying the continuous values of the pixels that have a large range of values. Since the UAV photogrammetry data were also collected for shallow coastal and transparent parts of the St. Anthony Channel, in future research we are planning to select a smaller area within which a bathymetry accuracy of this dataset (UAV photogrammetry) will be assessed. In this, the filtered MBES dataset will be used as the validation set.

The new high-resolution digital orthophoto (DOP) map of the St. Anthony Channel was also created with a spatial resolution of around $3 \mathrm{~cm}$. Furthermore, from the created model, various primary and secondary parameters (morphometric, hydrological, etc.) could be derived. For example, Figure 16 shows the measurement of specific profiles within the St. Anthony Channel through selected cross sections. The derived integral model can be used to perform 2D and 3D representations of the channel, which can then be used for promotional purposes and for making informative tourist boards aimed at informing and navigating interested users. 

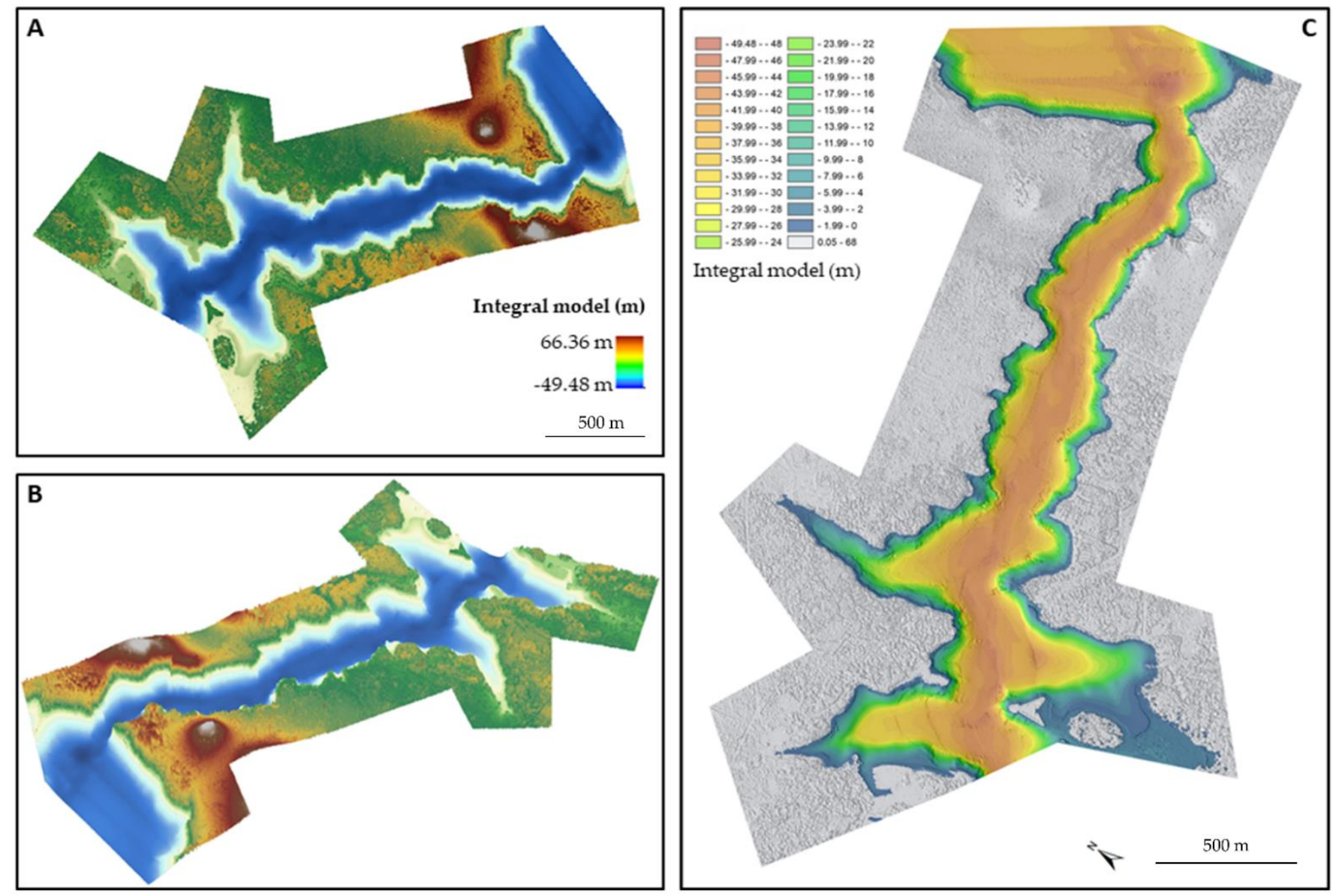

Figure 16. (A) The integral (MBES and UAV) model of the St. Anthony Channel; (B) the 3D view of the St. Anthony Channel; (C) the bathymetric map of the St. Anthony Channel.

\section{Conclusions}

In this study, we conducted a bathymetric survey using a multibeam system WASSP S3 multibeam wideband sounder temporarily installed on the small boat Luna. This paper explored the possibility of using a general user-friendly workflow for semi-automatic point cloud post-processing, consisting of subsequent steps performed using dedicated functions in the CloudCompare software. The reduction percentage in the MBES points after the denoising process was $14.11 \%(2,184,220)$. We believe that this methodological framework, based on open access CloudCompare 3D point cloud editing and processing software, can efficiently remove most of the outlier noise and be extremely useful if a user does not have a hydrographic survey package for the processing of MBES data. It achieves a balance between denoising and the preservation of underwater features. A high-resolution 3D model and detailed integral (DBM and DEM) model of the St. Anthony Channel was also created. The generated models can primarily be used for maritime safety and tourism promotion purposes. Future work will include the evaluation of the quality of the filtered dense point cloud using ground-truthing methods (e.g., ROVs) in order to validate the preservation of features on the seabed.

Author Contributions: Conceptualization, A.Š. and I.M.; methodology, A.Š., I.M., N.C. and L.P.; software, A.Š. and F.D.; formal analysis, N.C.; investigation, M.L. and L.P; resources, M.L.; data curation, I.M.; writing—original draft preparation, I.M.; writing—review and editing, F.D. and I.M; visualization, L.P.; supervision, N.C.; project administration, N.C. All authors have read and agreed to the published version of the manuscript.

Funding: This research received no external funding. 
Institutional Review Board Statement: This study did not involve humans or animals.

Informed Consent Statement: Not applicable.

Data Availability Statement: Data are available on request to the authors.

Acknowledgments: This work was supported in part by the Croatian Science Foundation under the project UIP-2017-05-2694 and by the Interreg Italy-Croatia PEPSEA project.

Conflicts of Interest: The authors declare no conflict of interest.

\section{References}

1. Parnum, I.M.; Gavrilov, A.N. High-frequency multibeam echo-sounder measurements of seafloor backscatter in shallow water: Part 1-Data acquisition and processing. Underw. Technol. 2011, 30, 3-12. [CrossRef]

2. Lecours, V.; Dolan, M.F.; Micallef, A.; Lucieer, V.L. A review of marine geomorphometry, the quantitative study of the seafloor. Hydrol. Earth Syst. Sci. 2016, 20, 3207. [CrossRef]

3. Huizinga, R.J.; Heimann, D.C. Hydrographic Surveys of Rivers and Lakes Using a Multibeam Echosounder Mapping System; US Department of the Interior, US Geological Survey: Reston, VA, USA, 2018.

4. Brown, C.J.; Beaudoin, J.; Brissette, M.; Gazzola, V. Multispectral multibeam echo sounder backscatter as a tool for improved seafloor characterization. Geosciences 2019, 9, 126. [CrossRef]

5. Smith Menandro, P.; Cardoso Bastos, A. Seabed Mapping: A Brief History from Meaningful Words. Geosciences 2020, 10, 273. [CrossRef]

6. Glenn, M.F. Introducing an operational multi-beam array sonar. Int. Hydrogr. Rev. 1970, 47, 35-39.

7. Wölfl, A.C.; Snaith, H.; Amirebrahimi, S.; Devey, C.W.; Dorschel, B.; Ferrini, V.; Huvenne, V.A.I.; Jackobsson, M.; Jencks, J.; Johnston, G.; et al. Seafloor Mapping-the challenge of a truly global ocean bathymetry. Front. Mar. Sci. 2019, 6, 283. [CrossRef]

8. Le Deunf, J.; Debese, N.; Schmitt, T.; Billot, R. A review of data cleaning approaches in a hydrographic framework with a focus on bathymetric multibeam echosounder datasets. Geosciences 2020, 10, 254. [CrossRef]

9. Ierodiaconou, D.; Schimel, A.C.; Kennedy, D.; Monk, J.; Gaylard, G.; Young, M.; Diesing, M.; Rattray, A. Combining pixel and object based image analysis of ultra-high resolution multibeam bathymetry and backscatter for habitat mapping in shallow marine waters. Mar. Geophys. Res. 2018, 39, 271-288. [CrossRef]

10. Brown, C.J. Benthic Habitat Mapping: From backscatter to biology. J. Ocean Technol. 2015, 10, 48-61.

11. Gee, L.; Doucet, M.; Parker, D.; Weber, T.; Beaudoin, J. Is multibeam water column data really worth the disk space? In Proceedings of the Hydro12-Taking Care of the Sea, San Diego, CA, USA, 13-15 November 2012; pp. 13-15.

12. Parnum, I.M.; Gavrilov, A.N.; Siwabessy, P.J.; Duncan, A.J. Analysis of high-frequency multibeam backscatter statistics from different seafloor habitats. In Proceedings of the Eighth European Conference on Underwater Acoustics, Carvoeiro, Portugal, 12-15 June 2006; pp. 775-780.

13. Diesing, M. Application of geobia to map the seafloor. In Proceedings of the GEOBIA 2016: Solution and Synergies, ITC/University of Twente, Enschede, Netherlands, 14-16 September 2016; p. 3.

14. Janowski, Ł.; Tęgowski, J.; Nowak, J. Seafloor mapping based on multibeam echosounder bathymetry and backscatter data using Object-Based Image Analysis: A case study from the Rewal site, the Southern Baltic. Oceanol. Hydrobiol. Stud. 2018, 47, 248-259. [CrossRef]

15. Schimel, A.C.; Healy, T.R.; Johnson, D.; Immenga, D. Quantitative experimental comparison of single-beam, sidescan, and multibeam benthic habitat maps. ICES J. Mar. Sci. 2010, 67, 1766-1779. [CrossRef]

16. Kjeldsen, K.K.; Weinrebe, R.W.; Bendtsen, J.; Bjørk, A.A.; Kjær, K.H. Multibeam bathymetry and CTD measurements in two fjord systems in southeastern Greenland. Earth Sci. Data 2017, 9, 589-600. [CrossRef]

17. Šiljeg, A.; Cavrić, B.; Marić, I.; Barada, M. GIS modelling of bathymetric data in the construction of port terminals-An example of Vlaška channel in the Port of Ploče, Croatia. Int. J. Eng. Model. 2019, 32, 17-37. [CrossRef]

18. Amirebrahimi, S.; Picard, K.; Quadros, N.; Falster, G. Multibeam Echo Sounder Data Acquisition in Australia and Beyond-User Needs Summary. Geosci. Aust. Rec. 2019, 8, 47.

19. Kostylev, V.E.; Todd, B.J.; Fader, G.B.J.; Courtney, R.C.; Cameron, G.D.M.; Pickrill, R.A. Benthic habitat mapping on the Scotian Shelf based on multibeam bathymetry, surficial geology and sea floor photographs. Mar. Ecol. Prog. Ser. 2001, 219, 121-137. [CrossRef]

20. Brown, C.J.; Smith, S.J.; Lawton, P.; Anderson, J.T. Benthic habitat mapping: A review of progress towards improved understanding of the spatial ecology of the seafloor using acoustic techniques. Estuar. Coast. Shelf Sci. 2011, 92, 502-520. [CrossRef]

21. Kostylev, V.E.; Courtney, R.C.; Robert, G.; Todd, B.J. Stock evaluation of giant scallop (Placopecten magellanicus) using highresolution acoustics for seabed mapping. Fish. Res. 2003, 60, 479-492. [CrossRef]

22. Šiljeg, A.; Marić, I.; Roland, V. Izrada tematskih karata na temelju podataka prikupljenih batimetrijskom izmjerom. Zbornik radova: Vizija i izazovi upravljanja zaštićenim područjima prirode u Republici Hrvatskoj-Aktivna zaštita i održivo upravljanje u Nacionalnom parku "Krka" / Marguš, Drago (ur.). Šibenik Javna Ustanov. 2017, 1, 994-1016. 
23. Madricardo, F.; Foglini, F.; Kruss, A.; Ferrarin, C.; Pizzeghello, N.M.; Murri, C.; Rossi, M.; Bajo, M.; Bellafiore, D.; Campiani, E.; et al. High resolution multibeam and hydrodynamic datasets of tidal channels and inlets of the Venice Lagoon. Sci. Data 2017, 4, 170121. [CrossRef]

24. Vogt, P.R.; Smoot, N.C. The Geisha Guyots: Multibeam bathymetry and morphometric interpretation. J. Geophys. Res. Solid Earth 1984, 89, 11085-11107. [CrossRef]

25. Lawver, L.A.; Sloan, B.J.; Barker, D.H.; Ghidella, M.; Von Herzen, R.P.; Keller, R.A.; Klinkhammer, G.P.; Chin, C.S. Distributed, active extension in Bransfield Basin, Antarctic Peninsula: Evidence from multibeam bathymetry. GSA Today 1996, 6, 1-6.

26. Wilson, M.F.J.; O'Connell, B.; Brown, C.; Guinan, J.C.; Grehan, A.J. Multiscale Terrain Analysis of Multibeam Bathymetry Data for Habitat Mapping on the Continental Slope. Mar. Geod. 2007, 30, 3-35. [CrossRef]

27. Dartnell, P.; Gardner, J.V. Predicting seafloor facies from multibeam bathymetry and backscatter data. Photogramm. Eng. Remote Sens. 2004, 70, 1081-1091. [CrossRef]

28. Bentrem, F.W.; Avera, W.E.; Sample, J. Estimating surface sediments using multibeam sonar. arXiv 2006, arXiv:0606191.

29. Moore, C.H.; Harvey, E.S.; Van Niel, K.P. Spatial prediction of demersal fish distributions: Enhancing our understanding of species-Environment relationships. ICES J. Mar. Sci. 2009, 66, 2068-2075. [CrossRef]

30. Hasan, R.C.; Ierodiaconou, D.; Rattray, A.; Monk, J.; Laurenson, L. Applications of multibeam echosounder data and video observations for biological monitoring on the south east Australian continental shelf. In Proceedings of the International Symposium and Exhibition on Geoinformation, Shah Alam, Malaysia, 27-29 September 2011; pp. 1-16.

31. Quinn, R.J.; Dix, J.K.; Dean, M. Chapter 13: Geophysical and remote sensing surveys. In Archaeology Underwater: The Nautical Archaeology Society Guide to Principles and Practice, 2nd ed.; Bowens, A., Ed.; Wiley-Blackwell: Oxford, UK, 2008.

32. Westley, K.; Quinn, R.; Forsythe, W.; Plets, R.; Bell, T.; Benetti, S.; McGrath, F.; Robinson, R. Mapping submerged landscapes using multibeam bathymetric data: A case study from the north coast of Ireland. Int. J. Naut. Archaeol. 2011, 40, 99-112. [CrossRef]

33. Plets, R.; Quinn, R.; Forsythe, W.; Westley, K.; Bell, T.; Benetti, S.; McGrath, F.; Robinson, R. Using multibeam echo-sounder data to identify shipwreck sites: Archaeological assessment of the joint Irish bathymetric survey data. Int. J. Naut. Archaeol. 2011, 40, 87-98. [CrossRef]

34. Kan, H.; Katagiri, C.; Nakanishi, Y.; Yoshizaki, S.; Nagao, M.; Ono, R. Assessment and Significance of a World War II battle site: Recording the USS Emmons using a High-Resolution DEM combining Multibeam Bathymetry and SfM Photogrammetry. Int. J. Naut. Archaeol. 2018, 47, 267-280. [CrossRef]

35. Pydyn, A.; Popek, M.; Kubacka, M.; Janowski, Ł. Exploration and reconstruction of a medieval harbour using hydroacoustics, 3-D shallow seismic and underwater photogrammetry: A case study from Puck, southern Baltic Sea. Archaeol. Prospect. 2021, 28, 527-542. [CrossRef]

36. Madricardo, F.; Bassani, M.; D'Acunto, G.; Calandriello, A.; Foglini, F. New evidence of a Roman road in the Venice Lagoon (Italy) based on high resolution seafloor reconstruction. Sci. Rep. 2021, 11, 1-19.

37. Bosman, A.; Romagnoli, C.; Madricardo, F.; Correggiari, A.; Remia, A.; Zubalich, R.; Fogarin, S.; Kruss, A.; Trincardi, F. Short-term evolution of Po della Pila delta lobe from time lapse high-resolution multibeam bathymetry (2013-2016). Estuar. Coast. Shelf Sci. 2020, 233, 106533. [CrossRef]

38. Pillay, T.; Cawthra, H.C.; Lombard, A.T. Characterisation of seafloor substrate using advanced processing of multibeam bathymetry, backscatter, and sidescan sonar in Table Bay, South Africa. Mar. Geol. 2020, 429, 106332. [CrossRef]

39. Chiocci, F.L.; Cattaneo, A.; Urgeles, R. Seafloor mapping for geohazard assessment: State of the art. Mar. Geophys. Res. 2011, 32, 1-11. [CrossRef]

40. Fenty, I.; Willis, J.K.; Khazendar, A.; Dinardo, S.; Forsberg, R.; Fukumori, I.; Holland, D.; Jakobsson, M.; Moller, D.; Morison, J.; et al. Oceans Melting Greenland: Early results from NASA's ocean-ice mission in Greenland. Oceanography 2016, $29,72-83$. [CrossRef]

41. Gula, J.; Molemaker, M.J.; McWilliams, J.C. Gulf Stream dynamics along the southeastern US seaboard. J. Phys. Oceanogr. 2015, 45, 690-715. [CrossRef]

42. Ellis, J.I.; Clark, M.R.; Rouse, H.L.; Lamarche, G. Environmental management frameworks for offshore mining: The New Zealand approach. Mar. Policy 2017, 84, 178-192. [CrossRef]

43. Nasby-Lucas, N.M.; Embley, B.W.; Hixon, M.A.; Merle, S.G.; Tissot, B.N.; Wright, D.J. Integration of submersible transect data and high-resolution multibeam sonar imagery for a habitat-based groundfish assessment of Heceta Bank. Fish Bull. 2002, 100, 739-751.

44. Hein, J.R.; Conrad, T.A.; Dunham, R.E. Seamount characteristics and mine-site model applied to exploration-and mining-leaseblock selection for cobalt-rich ferromanganese crusts. Mar. Georesources Geotechnol. 2009, 27, 160-176. [CrossRef]

45. Rengstorf, A.M.; Mohn, C.; Brown, C.; Wisz, M.S.; Grehan, A.J. Predicting the distribution of deep-sea vulnerable marine ecosystems using high-resolution data: Considerations and novel approaches. Deep. Sea Res. Part I Oceanogr. Res. Pap. 2014, 93, 72-82. [CrossRef]

46. Jordan, A.; Lawler, M.; Halley, V.; Barrett, N. Seabed habitat mapping in the Kent Group of islands and its role in marine protected area planning. Aquat. Conserv. Mar. Freshw. Ecosyst. 2005, 15, 51-70. [CrossRef]

47. Micallef, A.; Foglini, F.; Le Bas, T.; Angeletti, L.; Maselli, V.; Pasuto, A.; Taviani, M. The submerged paleolandscape of the Maltese Islands: Morphology, evolution and relation to Quaternary environmental change. Mar. Geol. 2013, 335, 129-147. [CrossRef] 
48. Kulawiak, M.; Lubniewski, Z. Processing of LiDAR and multibeam sonar point cloud data for 3D surface and object shape reconstruction. In Proceedings of the 2016 Baltic Geodetic Congress (BGC Geomatics), Gdansk, Poland, 2-4 June 2016; IEEE: Gdansk, Poland, 2016; pp. 187-190.

49. Moszynski, M.; Chybicki, A.; Kulawiak, M.; Lubniewski, Z. A novel method for archiving multibeam sonar data with emphasis on efficient record size reduction and storage. Pol. Marit. Res. 2013, 20, 77-86. [CrossRef]

50. Nathalie, D.; Thierry, S.; François, G.; Etienne, J.; Lucas, V.; Romain, B. Outlier detection for Multibeam echo sounder (MBES) data: From past to present. In Proceedings of the IEEE Oceans 2019, Marseille, France, 17-20 June 2019; pp. 1-10.

51. Ferreira, I.O.; Santos, A.D.P.D.; Oliveira, J.C.D.; Medeiros, N.D.G.; Emiliano, P.C. Robust methodology for detection of spikes in multibeam echo sounder data. Bol. Ciências Geodésicas 2019, 25, e2019014. [CrossRef]

52. Makar, A. Algorithms for Cleaning the Data Recorded by Multibeam Echosounder. In International Conference on Geo Sciences GEOLINKS 2019; Saima Consult LTD: Athens, Greece, 2019; Volume 1, pp. 259-266.

53. Stevens, A.H.; Butkiewicz, T. Faster Multibeam Sonar Data Cleaning: Evaluation of Editing 3D Point Clouds using Immersive VR. In Proceedings of the OCEANS 2019 MTS/IEEE, Seattle, WA, USA, 27-31 October 2019; IEEE: Seattle, WA, USA, 2019; pp. 1-10.

54. Arge, L.; Larsen, K.G.; Mølhave, T.; van Walderveen, F. Cleaning massive sonar point clouds. In Proceedings of the 18th SIGSPATIAL International Conference on Advances in Geographic Information Systems, San Jose, CA, USA, 2-5 November 2010; pp. 152-161.

55. Rakotosaona, M.J.; La Barbera, V.; Guerrero, P.; Mitra, N.J.; Ovsjanikov, M. Pointcleannet: Learning to denoise and remove outliers from dense point clouds. Comput. Graph. Forum 2020, 39, 185-203. [CrossRef]

56. Chen, C.; Gawel, A.; Krauss, S.; Zou, Y.; Abbott, A.L.; Stilwell, D.J. Robust Unsupervised Cleaning of Underwater Bathymetric Point Cloud Data. In Proceedings of the 31st British Machine Vision Virtual Conference, Online, 7-10 September 2020.

57. Hodge, V.; Austin, J. A survey of outlier detection methodologies. Artif. Intell. Rev. 2004, 22, 85-126. [CrossRef]

58. Santos, A.M.R.T.; Santos, G.R.D.; Emiliano, P.C.; Medeiros, N.D.G.; Kaleita, A.L.; Pruski, L.D.O.S. Detection of inconsistencies in geospatial data with geostatistics. Bol. De Ciências Geodésicas 2017, 23, 296-308. [CrossRef]

59. Debese, N. Bathymétrie-Sondeurs, Traitement des Données Modèles Numériques de Terrain-Cours Exercices Corrigés; Ellipses: Paris, France, 2013.

60. Calder, B.R.; Mayer, L.A. Automatic processing of high-rate, high-density multibeam echosounder data. Geochem. Geophys. Geosyst. 2003, 4, 1-22. [CrossRef]

61. Calder, B.R. Automatic statistical processing of multibeam echosounder data. Int. Hydro. Rev. 2003, 4, 36-52.

62. Vaaja, M.; Kukko, A.; Kaartinen, H.; Kurkela, M.; Kasvi, E.; Flener, C.; Hyyppä, H.; Järvelä, J.; Alho, P. Data processing and quality evaluation of a boat-based mobile laser scanning system. Sensors 2013, 13, 12497-12515. [CrossRef]

63. Carić, H.; Cukrov, N.; Omanović, D. Nautical Tourism in Marine Protected Areas (MPAs): Evaluating an Impact of Copper Emission from Antifouling Coating. Sustainability 2021, 13, 11897. [CrossRef]

64. Belamarić, G.; Kurtela, Ž.; Bošnjak, R. Simulation method-based oil spill pollution risk analysis for the port of šibenik. Trans. Marit. Sci. 2016, 5, 141-154. [CrossRef]

65. Lovrinčević, D. Quality assessment of an automatic sounding selection process for navigational charts. Cartogr. J. 2017, 5, 139-146. [CrossRef]

66. IHB. Manual on Hydrography Publication C-13, 1st ed.; International Hydrographic Bureau: Monte Carlo, Monaco, 2005.

67. Weatherall, P.; Marks, K.M.; Jakobsson, M.; Schmitt, T.; Tani, S.; Arndt, J.E.; Rovere, M.; Chayes, D.; Ferrini, V.; Wigley, R. A new digital bathymetric model of the world's oceans. Earth Space Sci. 2015, 2, 331-345. [CrossRef]

68. Hell, B.; Broman, B.; Jakobsson, L.; Jakobsson, M.; Magnusson, A.; Wiberg, P. The use of bathymetric data in society and science: A review from the Baltic Sea. Ambio 2012, 41, 138-150. [CrossRef] [PubMed]

69. Geomatching. Multibeam EchoScounder. Available online: https://geo-matching.com/multibeam-echosounders (accessed on 29 November 2021).

70. Wassp Multibeam. Available online: https://www.enl.co.nz/pages/wassp-s3 (accessed on 29 November 2021).

71. Nugraha, W.; Parapat, A.D.; Arum, D.S.; Istighfarini, F. GNSS RTK Application to Determine Coastline Case Study at Northen Area of Sulawesi and Gorontalo. E3S Web Conf. 2019, 94, 01016. [CrossRef]

72. Hemisphere GNSS. Vector V320 GNSS Smart Antenna User Guide Part No. 875-0351-0 Rev. A1. 2015. Available online: https: //hemispheregnss.com/wp-content/uploads/2018/12/hemispheregnss_v320_ug_userguide_875-0351-0_a1-1.pdf (accessed on 9 December 2020).

73. Šantek, D. Ispitivanje CROPOS-a. Geod. List. 2013, 67, 281-297.

74. Montereale-Gavazzi, G.; Roche, M.; Lurton, X.; Degrendele, K.; Terseleer, N.; Van Lancker, V. Seafloor change detection using multibeam echosounder backscatter: Case study on the Belgian part of the North Sea. Mar. Geophys. Res. 2018, 39, 229-247. [CrossRef]

75. YSI, EXO2 Multiparameter Sond. Available online: https://www.ysi.com/exo2 (accessed on 29 November 2021).

76. Dong, Q.L.; Cui, M.X.; Zhou, J.H.; Wang, J.G.; Xu, Y. Analysis and Processing of Transform Geography of Convex and Cave in Multibeam Sounding System. Hydrogr. Surv. Charting 2011, 1, 32-35.

77. Dong, Q.L.; Han, H.Q.; Fang, Z.B.; Pan, L.; Chen, Y.Y.; Lu, G.F. The Influence of Sound Speed Profiles Correction on Multi-beam Survey. Hydrogr. Surv. Charting 2007, 2, 56-58. 
78. CloudCompare, CloudCompare 3D Point Cloud and Mesh Processing Software Open Source Project. Available online: https: / / cloudcompare.org (accessed on 20 August 2020).

79. Skinner, B.; Vidal-Calleja, T.; Miro, J.V.; De Bruijn, F.; Falque, R. 3D point cloud upsampling for accurate reconstruction of dense $2.5 \mathrm{D}$ thickness maps. In Proceedings of the Australasian Conference on Robotics and Automation, ACRA, Melbourne, Australia, 2-4 December 2014.

80. Charron, N.; Phillips, S.; Waslander, S.L. De-noising of lidar point clouds corrupted by snowfall. In Proceedings of the 201815 th Conference on Computer and Robot Vision (CRV), Toronto, ON, Canada, 9-11 May 2018; pp. 254-261.

81. Ruchay, A.N.; Dorofeev, K.A.; Kalschikov, V.V. Accuracy analysis of 3D object reconstruction using point cloud filtering algorithms. In Proceedings of the 5th Information Technology and Nanotechnology, ITNT-2019, Samara, Russia, 21-24 May 2019.

82. Abdelazeem, M.; Elamin, A.; Afifi, A.; El-Rabbany, A. Multi-sensor point cloud data fusion for precise 3D mapping. Egypt. J. Remote Sens. Space Sci. 2021, 24, 835-844. [CrossRef]

83. Zeybek, M. Inlier Point Preservation in Outlier Points Removed from the ALS Point Cloud. J. Indian Soc. Remote Sens. 2021, 49, 2347-2363. [CrossRef]

84. Carrilho, A.C.; Galo, M.; Santos, R.C. Statistical outlier detection method for airborne lidar data. In Proceedings of the International Archives of the Photogrammetry, Remote Sensing and Spatial Information Sciences, Volume XLII-1, ISPRS TC I Mid-term Symposium "Innovative Sensing-From Sensors to Methods and Applications", Karlsruhe, Germany, 10-12 October 2018.

85. Chen, S.; Truong-Hong, L.; O’Keeffe, E.; Laefer, D.F.; Mangina, E. Outlier detection of point clouds generating from low cost UAVs for bridge inspection. In Life-Cycle Analysis and Assessment in Civil Engineering: Towards an Integrated Vision; Caspeele, R., Taerwe, L., Frangopol, D.M., Eds.; CRC Press: Ghent, Belgium, 2018.

86. Kharroubi, A.; Hajji, R.; Billen, R.; Poux, F. Classification and integration of massive 3d points clouds in a virtual reality (VR) environment. International Archives of the Photogrammetry. Remote Sens. Spat. Inf. Sci. 2019, 42, 165-171.

87. CloudCompare, Label Connected Components. Available online: https: / / www.cloudcompare.org $/$ doc $/$ wiki $/$ index.php?title= Label_Connected_Components (accessed on 14 December 2020).

88. Kaňuk, J.; Šupinský, J.; Šašak, J.; Hofierka, J.; Wang, Y.; Zhang, Q.; Sedlák, V.; Onačillová, K.; Gallay, M. Semi-automatic LiDAR point cloud denoising using a connected-component labelling method. Geogr. Cassoviensis 2019, 13, 210-227. [CrossRef]

89. Cai, S.; Zhang, W.; Liang, X.; Wan, P.; Qi, J.; Yu, S.; Yan, G.; Shao, J. Filtering airborne LiDAR data through complementary cloth simulation and progressive TIN densification filters. Remote Sens. 2019, 11, 1037. [CrossRef]

90. Lee, J.B.; Jung, J.H.; Kim, H.J. Segmentation of Seabed Points from Airborne Bathymetric LiDAR Point Clouds Using Cloth Simulation Filtering Algorithm. J. Korean Soc. Surv. Geod. Photogramm. Cartogr. 2020, 38, 1-9. [CrossRef]

91. Zhang, W.; Qi, J.; Wan, P.; Wang, H.; Xie, D.; Wang, X.; Yan, G. An easy-to-use airborne LiDAR data filtering method based on cloth simulation. Remote Sens. 2016, 8, 501. [CrossRef]

92. Yang, F.; Li, J.; Wu, Z.; Jin, X.; Chu, F.; Kang, Z. A post-processing method for the removal of refraction artifacts in multibeam bathymetry data. Mar. Geod. 2007, 30, 235-247. [CrossRef]

93. Yang, F.; Li, J.; Han, L.; Liu, Z. The filtering and compressing of outer beams to multibeam bathymetric data. Mar. Geophys. Res. 2013, 34, 17-24. [CrossRef]

94. Sui, B.; Zheng, Y.P.; Liu, B.H. Analysis of acoustic velocity error for Seabeam 2100 multibeam system. Adv. Mar. Sci. 2004, 22, 77-84.

95. CloudCompare, CSF Plugin. Available online: https://www.cloudcompare.org/doc/wiki/index.php?title=CSF_(plugin) (accessed on 29 November 2021).

96. Šiljeg, A.; Barada, M.; Marić, I. Digitalno Modeliranja Reljefa; Sveučilište u Zadru, Alfa d.o.o.: Zadar, Croatia, 2018.

97. Hughes Clarke, J.E. The impact of acoustic imaging geometry on the fidelity of seabed bathymetric models. Geosciences 2018, 8 , 109. [CrossRef]

98. Hengl, T. Finding the right pixel size. Comput. Geosci. 2006, 32, 1283-1298. [CrossRef] 